Reference

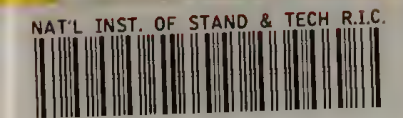

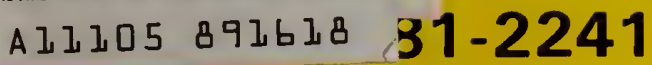

NBS

Publi-

cations

\title{
Engineering - Economic Analysis of Improved Heat Pump Performance for Minimum Standards Development
}

U.S. DEPARTMENT OF COMMERCE

National Bureau of Standards

National Engineering Laboratory

Center for Building Technology

Washington, DC 20234

July 1981

Sponsored by

Office of Buildings and Community Systems

II.S. Department of Energy

$-Q C$ 'ashington, DC

100

.456

81-2241

1981 



\section{ENGINEERING - ECONOMIC ANALYSIS \\ OF IMPROVED HEAT PUMP \\ PERFORMANCE FOR MINIMUM \\ STANDARDS DEVELOPMENT}

Stephen R. Petersen

Kimberly A. Barnes

George E. Kelly

U.S. DEPARTMENT OF COMMERCE

National Bureau of Standards

National Engineering Laboratory

Center for Building Technology

Washington, DC 20234

July 1981

Sponsored by

Office of Buildings and Community Systems

U.S. Department of Energy

Washington, DC

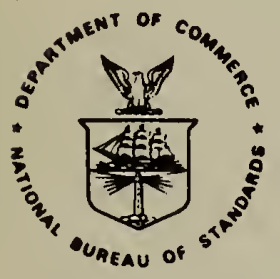

U.S. DEPARTMENT OF COMMERCE, Malcolm Baldrige, Secretary NATIONAL BUREAU OF STANDARDS, Ernest Ambler, Director 


$$
\because=5+21
$$


The work in this report has been conducted as an interdisciplinary research project by the Building Economics and Regulatory Technology Division and the Building Thermal and Service Systems Division within the Center for Building Technology, National Engineering Laboratory, at the National Bureau of Standards (NBS). This effort has been supported by the Consumer Product Efficiency Branch in the Office of Buildings and Community Systems, at the U.S. Department of Energy (DoE).

The methodology outlined in this report employs a parametric analysis technique. The numerical values resulting from this analysis are valid only for the specified set of parameters selected by NBS. DoE is required by law to consider many other factors in setting minimum efficiency standards. 


\section{ABSTRACT}

This report provides a methodology and technical data for analyzing the life-cycle cost effectiveness of energy efficiency improvements to residential heat pump systems. This methodology could be used to develop a reference base for establishing minimum efficiency standards for new heat pump systems that are economically justified in a prescribed percentage of installations. Criteria for economic optimization are outlined. The methodology used to compute seasonal heating and cooling performance ratings and the annual energy savings resulting from improvements in seasonal performance, by climate region, are detailed. The interdependence between efficiency ratings in the heating and cooling modes is explored using statistical analysis. An example of the procedure for determining maximum cost-effective efficiency levels is demonstrated for a $36,000 \mathrm{Btu} / \mathrm{h}$ heat pump.

Keywords: energy efficiency standards; engineering-economic analysis; heat pump; mechanical equipment efficiency ratings; minimum efficiency standards; space cooling requirements; space heating requirements. 


\section{ACKNOWLEDGMENTS}

The authors wish to thank the following people at the National Bureau of Standards for their timely review and helpful comments: Harold E. Marshall, David A. Didion, Peter Domanski, W. B. May, and Clinton W. Phillips. Errors and omissions remain the responsibility of the authors. 
LIST OF TABLES $\ldots \ldots \ldots \ldots \ldots \ldots \ldots \ldots \ldots \ldots \ldots \ldots \ldots \ldots \ldots \ldots \ldots \ldots \ldots \ldots \ldots \ldots \ldots \ldots$

LIST OF FIGURES $\ldots \ldots \ldots \ldots \ldots \ldots \ldots \ldots \ldots \ldots \ldots \ldots \ldots \ldots \ldots \ldots \ldots \ldots \ldots \ldots \ldots \ldots \ldots \ldots \ldots \ldots$ vili

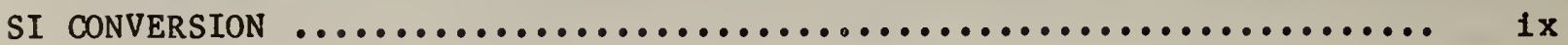

1. INTRODUCTION $\ldots \ldots \ldots \ldots \ldots \ldots \ldots \ldots \ldots \ldots \ldots \ldots \ldots \ldots \ldots \ldots \ldots \ldots \ldots \ldots \ldots \ldots$

2. GENERAL METHODOLOGY FOR ESTABLISHING OPTIMAL PERFORMANCE LEVELS FOR HEAT PUMPS

2.1 GENERAL ECONOMIC CRITERION FOR OPTIMIZATION ............. 3

2.2 COMPUTATION OF INCREMENTAL SAVINGS AND COSTS FOR HEAT PUMP SYSTEMS

3. CALCULAT ING THE SEASONAL PERFORMANCE OF HEAT PUMPS IN THE hEAT ING

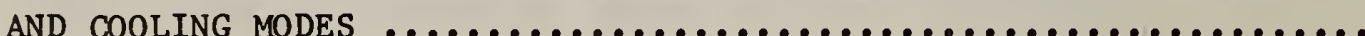

3.1 COOLING MODE CALCULAT IONS $\ldots \ldots \ldots \ldots \ldots \ldots \ldots \ldots \ldots \ldots \ldots \ldots \ldots \ldots$

3.2 HEATING MODE CALCULATIONS $\ldots \ldots \ldots \ldots \ldots \ldots \ldots \ldots \ldots \ldots \ldots \ldots \ldots \ldots \ldots \ldots \ldots$

3.3 INTERRELAT IONSHIP BETWEEN PERFORMANCE CHARACTERISTICS IN THE HEATING AND COOLING MODES .......................... 13

3.4 INTERRELAT IONSHIP BETWEEN SEASONAL PERFORMANCE CHARACTERISTICS IN THE HEATING AND COOLING MODES ................. 18

4. EST IMAT ING ANNUAL ENERGY SAVINGS $\ldots \ldots \ldots \ldots \ldots \ldots \ldots \ldots \ldots \ldots \ldots \ldots \ldots \ldots \ldots \ldots$

4.1 GENERAL METHOD ................................. 26

4.2 ANNUAL HEATING AND COOLING REQUIREMENTS FROM THE BEPS

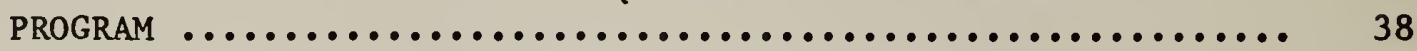

5. DETERMINATION OF MAXIMUM COST-EFFECTIVE EFFICIENCY LEVELS $\ldots \ldots \ldots \ldots$

6. SUMMARY, CONCLUSIONS, AND RECOMMENDAT IONS FOR FURTHER RESEARCH .... 52

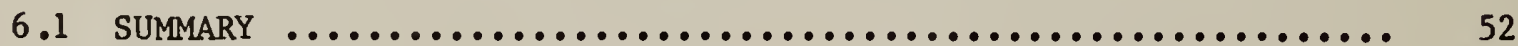

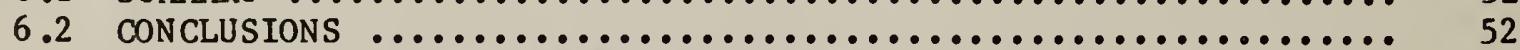

6.3 RECOMMENDATIONS FOR FURTHER RESEARCH $\ldots \ldots \ldots \ldots \ldots \ldots \ldots \ldots \ldots \ldots \ldots . \ldots \ldots$

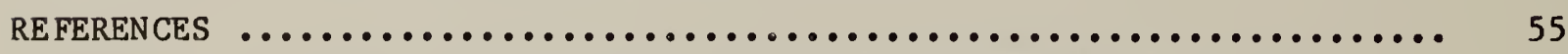
APPENDIX A - DERIVATION OF MODIFIED UNIFORM PRESENT WORTH FACTORS .... 56 


\section{LIST OF TABLES}

Table

Page

1 Major Heating Climate Regions in the Continental U.S.A. .....

HSPF by Heating Climate Region: $24,000 \mathrm{Btu} / \mathrm{h}$ Capacity $\left(95^{\circ} \mathrm{F}\right)$,

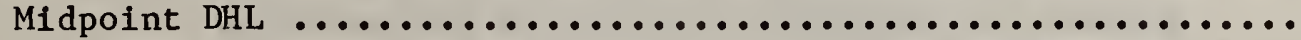

3 HSPF by Heating Climate Region: $24,000 \mathrm{Btu} / \mathrm{h}$ Capacity $\left(95^{\circ} \mathrm{F}\right)$,

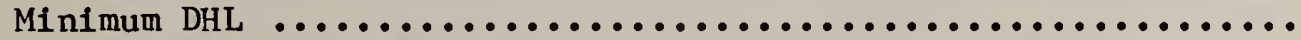

HSPF by Heating Climate Region: $24,000 \mathrm{Btu} / \mathrm{h}$ Capacity $\left(95^{\circ} \mathrm{F}\right)$,

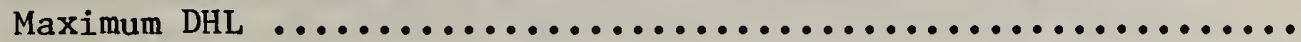

HSPF by Heating Climate Region: $18,000 \mathrm{Btu} / \mathrm{h}$ Capacity $\left(95^{\circ} \mathrm{F}\right)$,

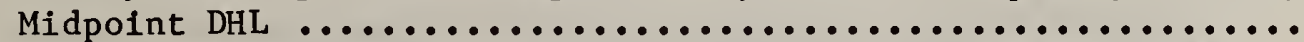

HSPF by Heating Climate Region: $36,000 \mathrm{Btu} / \mathrm{h}$ Capacity $\left(95^{\circ} \mathrm{F}\right)$,

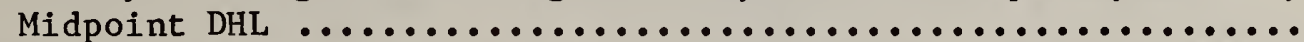

HSPF by Heating Climate Region: $48,000 \mathrm{Btu} / \mathrm{h}$ Capacity $\left(95^{\circ} \mathrm{F}\right)$,

Midpoint DHL .................................

Cooling Climate Regions $\ldots \ldots \ldots \ldots \ldots \ldots \ldots \ldots \ldots \ldots \ldots \ldots \ldots \ldots$

Combined Climate Regions

Annual $\mathrm{kWh}$ Usage for a $24,000 \mathrm{Btu} / \mathrm{h}$ Heat Pump by Combined

Climate Region (General Method) ......................

Reduction in Annual $\mathrm{kWh}$ Usage Due to Increased Efficiency:

$24,000 \mathrm{Btu} / \mathrm{h}$ Heat Pump (General Method) .................

Reduction in Annual $\mathrm{kWh}$ Usage Due to Increased Efficiency:

$18,000 \mathrm{Btu} / \mathrm{h}$ Heat Pump (General Method) ..................

Reduction in Annual $\mathrm{kWh}$ Usage Due to Increased Efficiency:

$36,000 \mathrm{Btu} / \mathrm{h}$ Heat Pump (General Method) .................

Reduction in Annual $\mathrm{kWh}$ Usage Due to Increased Efficiency:

$48,000 \mathrm{Btu} / \mathrm{h}$ Heat Pump (General Method) .................

Space Heating and Cooling Data from BEPS .................

Estimated Space Heating and Cooling Requirements for BEPS

House ........................................

Incremental kWh Savings: BEPS-Based; $12,000 \mathrm{Btu} / \mathrm{h}$ Heat

Pump ........................................

Estimated Space Heating and Cooling Requirements Cor-

responding to a $12,000 \mathrm{Btu} / \mathrm{h}$ Heat Pump ..................

Incremental kWh Savings: General Method; $12,000 \mathrm{Btu} / \mathrm{h}$ Heat

Pump .........................................

Incremental Life-Cycle Savings Due to Increased Efficiency: $36,000 \mathrm{Btu} / \mathrm{h}$ Heat Pump $\ldots \ldots \ldots \ldots \ldots \ldots \ldots \ldots \ldots \ldots \ldots$ 
LIST OF FIGURES

Figure

1

2

3

4

5
Life-Cycle Appliance-Related Costs

Economically Optimal Appliance Efficiency Varies with

Assumptions Governing Incremental Dollar-Value

Energy Savings

Distribution of Heating Load Hours Throughout the United

States

Distribution of Cooling Load Hours Throughout the United

States

Illustration of Incremental Savings and Costs of $0.5 \mathrm{Btu} / \mathrm{Wh}$

Increase in SEER: $36,000 \mathrm{Btu} / \mathrm{h}$ Heat Pump
Page

4

6

28

29

49

viii 


\section{SI CONVERSION}

Because the energy analysis in this report is based directly on the NBS testing and rating procedure for heat pumps operated in the heating and cooling modes and on the capacities of heat pumps as typically rated by U S. manufacturers, compatible U.S. units of measurement are used throughout this report. Since the United States is a signatory to the Eleventh General Conference on Weights and Measures, which defined and gave official status to the Metric SI system, the following conversion factors are provided to assist users of SI units.

\section{Metric Conversion Factors}

\begin{tabular}{|c|c|}
\hline Length: & $\begin{array}{l}1 \text { inch }(\mathrm{in})=25.4 \text { millimeters }(\mathrm{mm}) \\
1 \text { foot }(\mathrm{ft})=0.3048 \text { meter }(\mathrm{m})\end{array}$ \\
\hline Area: & $1 \mathrm{ft}^{2}=0.092903 \mathrm{~m}^{2}$ \\
\hline $\begin{array}{l}\text { Volume: } \\
\text { Fluid Capacity: } \\
\text { Temperature: }\end{array}$ & $\begin{array}{l}\mathrm{I} \mathrm{ft}^{3}=0.028317 \mathrm{~m}^{3} \\
1 \text { gallon }(\mathrm{gal})=3.78541 \text { liters }(\mathrm{L}) \\
1^{\circ} \mathrm{F}=9 / 5^{\circ} \mathrm{C}+32\end{array}$ \\
\hline $\begin{array}{l}\text { Temperature } \\
\text { Interval: }\end{array}$ & $1^{\circ} \mathrm{F}=5 / 9^{\circ} \mathrm{C}$ or $\mathrm{K}$ \\
\hline Mass: & 1 pound $(1 \mathrm{~b})=0.453592 \mathrm{kilogram}(\mathrm{kg})$ \\
\hline $\begin{array}{l}\text { Mass per unit } \\
\text { Length: }\end{array}$ & $11 \mathrm{~b} / \mathrm{ft}=1.48816 \mathrm{~kg} / \mathrm{m}$ \\
\hline $\begin{array}{l}\text { Mass per unit } \\
\text { Area: }\end{array}$ & $1 \mathrm{lb} / \mathrm{ft}^{2}=4.88243 \mathrm{~kg} / \mathrm{m}^{2}$ \\
\hline $\begin{array}{l}\text { Mass per unit } \\
\text { Volume: }\end{array}$ & $11 \mathrm{~b} / \mathrm{ft}^{3}=16.0185 \mathrm{~kg} / \mathrm{m}^{3}$ \\
\hline $\begin{array}{l}\text { Energy: } \\
\text { Heat Flow Rate: } \\
\text { Specific Heat: }\end{array}$ & $\begin{array}{l}1 \mathrm{Btu}=1.05506 \text { kilojoules }(\mathrm{kJ}) \\
1 \mathrm{Btu} / \mathrm{h}=0.293071 \text { Watt }(\mathrm{W}) \\
1 \mathrm{Btu} /(1 \mathrm{~b})\left({ }^{\circ} \mathrm{F}\right)=4.1868 \mathrm{~kJ} /(\mathrm{kg})(\mathrm{K})\end{array}$ \\
\hline U-value: & $1 \mathrm{Btu} /\left(\mathrm{ft}^{2}\right)(\mathrm{h})\left({ }^{\circ} \mathrm{F}\right)=5.67826 \mathrm{~W} /\left(\mathrm{m}^{2}\right)(\mathrm{K})$ \\
\hline R-value: & $1\left(\mathrm{ft}^{2}\right)(\mathrm{h})\left({ }^{\circ} \mathrm{F}\right) / \mathrm{Btu}=0.176110\left(\mathrm{~m}^{2}\right)(\mathrm{K}) / \mathrm{W}$ \\
\hline
\end{tabular}





\section{INTRODUCT ION}

Minimum energy efficiency standards for air-to-air residential heat pumps are expected to be promulgated by the Department of Energy in the early $1980^{\prime} \mathrm{s.}^{1}$ These standards will apply to all heat pumps manufactured in the United States after the date of promulgation. It is likely that they will require that both the seasonal performance factor for heating (HSPF) and seasonal energy efficiency ratio (SEER) for cooling by air-to-air residential heat pumps equal or exceed minimum specifications to be determined by DoE. Because these are performance standards, rather than prescriptive standards, the actual methods and designs used to achieve these minimum efficiency levels will not be specified. However, the methodology and test procedures for calculating HSP F and SEER for each heat pump model will be specified by DoE in order to assure consistency. ${ }^{2}$

The energy efficiency standards for heat pumps are to be designed to achieve the maximum improvement in energy efficiency which DoE determines to be technologically feasible and economically justified. ${ }^{3}$ The purpose of this report is to develop a benefit-cost methodology, based on engineering-economic analysis, that can be used to provide DoE with reference data for minimum standards development that satisfies the criterion for economic justification. It will be shown that this criterion is likely to constrain the standard from reaching the energy efficiency level that is technologically feasible at this time.

Cost effectiveness is measured in this report in a life-cycle cost context. To be economically justified, each improvement in energy efficiency must result in additional life-cycle energy savings having a present dollar value greater than or equal to the corresponding additional costs. The highest energy efficiency levels (i.e., HSPF and SEER) which can be shown to be economically justified would serve as the basis for the DoE minimum standards for heat pumps.

1 U.S. Department of Energy, "Advance Notice of Proposed Rulemaking and Notice of Public Meetings Regarding Energy Efficiency Standards for Nine Types of Consumer Products," Federal Register, Vo1.44, No. 1, January 2, 1979, pp. 49-60.

2 The procedures for calculating both HSPF and SEER are specified in "Test Procedures for Central Air Conditioners, Including Heat Pumps," Department of Energy Final Rule, Federal Register, Vo1. 44, No. 249, December 27, 1979, pp. 76700-76723. The procedure for calculating HSP F is specified in W. Parken, G. Kelly, and D. Didion, Method of Testing, Rating, and Estimating the Heating Seasonal Performance of Heat Pumps, NBSIR 80-2002, Nationa1 Bureau of Standards, Washington, D.C., April 1980. The procedure for calculating SEER is specified in G. Kelly and W. Parken, Method of Testing, Rating and Estimating the Seasonal Performance of Central Air-Conditioners and Heat Pumps Operating in the Cooling Mode, NBSIR 77-1271, National Bureau of Standards, Washington, D.C., Apri1 1978.

3 U.S. Department of Energy, "Advance Notice of Proposed Rulemaking," p. 52. 
It should be recognized at the outset, however, that life-cycle savings, and thus the cost effectiveness of increases in heat pump efficiency, will vary significantly from installation to installation due to a number of factors, including climate, house design, operational profile, energy prices, and the discount rate used to convert future savings to present value. This wide variation in projected dollar-value energy savings is important in light of the high probability that DoE will establish a single standard for air-to-air residential heat pumps, regardless of the geographic location and house design in which the heat pump will be installed. As a result, the criteria for establishing minimum performance standards should seek to assure that such standards are cost-effective in the greater majority of installations. A methodology for estimating the approximate percentage of installations in which a given minimum efficiency standard is economically justified is developed in this report.

Scope. This report is primarily intended to provide a methodology for the engineering-economic analysis of air-to-air residential heat pumps in the approximate range of 14,000 to $60,000 \mathrm{Btu}$ per hour (Btu/h) output capacity in the cooling mode. This corresponds to an output capacity of approximately 14,000 to $65,000 \mathrm{Btu} / \mathrm{h}$ in the heating mode. Only heat pumps which provide both heating and cooling are examined. The analysis will consider installations in all geographic regions in the United States where heat pumps are used in more than token numbers. Energy savings will be calculated for improvements in heat pump efficiency ranging from an SEER of 7.0 to $11.0 \mathrm{Btu} / \mathrm{Wh}$, with corresponding changes in HSPF by heating region. The methodology for determining the maximum heat pump efficiency levels that are cost-justified is demonstrated for a $36,000 \mathrm{Btu} / \mathrm{h}$ heat pump.

Organization. In section 2, the economic criteria for determining the optimal level of operating efficiency are outlined. In section 3 , the methodologies for calculating the seasonal performance of a heat pump in both the heating and cooling modes are stated. In addition, the interrelationships between both steady-state and seasonal heating and cooling efficiencies are quantified. In section 4, annual energy savings due to specified improvements in heating and cooling efficiencies are calculated for a wide range of climates. In section 5, the methodology for determining maximum cost-effective levels of efficiency is demonstrated for a $36,000 \mathrm{Btu} / \mathrm{h}$ heat pump. Conclusions and recommendations for further research are discussed in section 6 . 


\section{GENERAL METHODOLOGY FOR ESTABLISHING OPTIMAL PERFORMANCE LEVELS FOR HEAT PUMPS}

\subsection{GENERAL ECONOMIC CRITERION FOR OPT IMIZATION}

The maximum improvement in energy efficiency which can be economically justified for any given appliance can be identified most readily in a 1ife-cycle cost context. Life-cycle costs include all costs incurred over the life of an appliance resulting from its installation and use. These costs include not only the initial installed cost, but energy, maintenance, and repair costs over the useful life of the appliance, all evaluated on a time equivalent basis, for example, discounted to present value ${ }^{1}$. The level of energy efficiency which minimizes total life-cycle costs attributable to an appliance is considered to be economically optimal. Any further increase in energy efficiency will not be cost effective. This relationship between energy efficiency and economic optimality is shown in figure 1.

At the top of figure 1 , the generalized relationship between increased efficiency (on the horizontal axis) and life-cycle energy costs (measured in present-value dollars on the vertical axis) is shown for a given appliance operated in a specified manner. As the efficiency increases linearly, the life-cycle energy costs decrease, but at a decreasing rate, since energy usage is inversely proportional to the efficiency rating. In addition, both the installed cost and life-cycle maintenance and repair costs of the appliance are shown in figure 1 as a function of appliance energy efficiency. As energy efficiency is upgraded, the installed appliance cost rises at an increasing rate due to the more intensive design changes needed to achieve each additional improvement. Life-cycle maintenance and repair costs may be constant or may change (upward or downward) as a function of appliance efficiency ratings. The total life-cycle cost (TLCC) curve is shown at the top of figure 1 . This is the sum of the installed cost and life-cycle energy, maintenance, and repair costs for any given level of appliance efficiency. As is typical of most energy using systems, improvements in energy efficiency at first reduce TLCC. At the optimal efficiency level, designated $\bar{\eta}$ in figure 1 , TLCC is minimized. At any point beyond $\bar{n}$, TLCC is increasing so that no increase in energy efficiency beyond $\bar{n}$ can be cost justified to the consumer.

This same optimal efficiency level can be identified by evaluating only incremental savings and costs attributable to small increases in efficiency as shown in the bottom of figure 1. Incremental savings (in present-value dollar terms) correspond to the reduction in life-cycle energy costs for each additional unit of efficiency improvement. Incremental costs include both the increase in installed cost plus the change in maintenance and repair costs (if any) attributable to the same efficiency improvement.

1 Alternatively, an equivalent annual cost can be determined. However, in the methodology presented all costs will be evaluated in present-value terms. For an in-depth examination of alternative economic optimization methods and discounting procedures, see $H$. Marshall and R. Ruegg, Simplified Energy Design Economics, NBS SP 544, Nationa1 Bureau of Standards, Washington, D.C., January 1980 . 


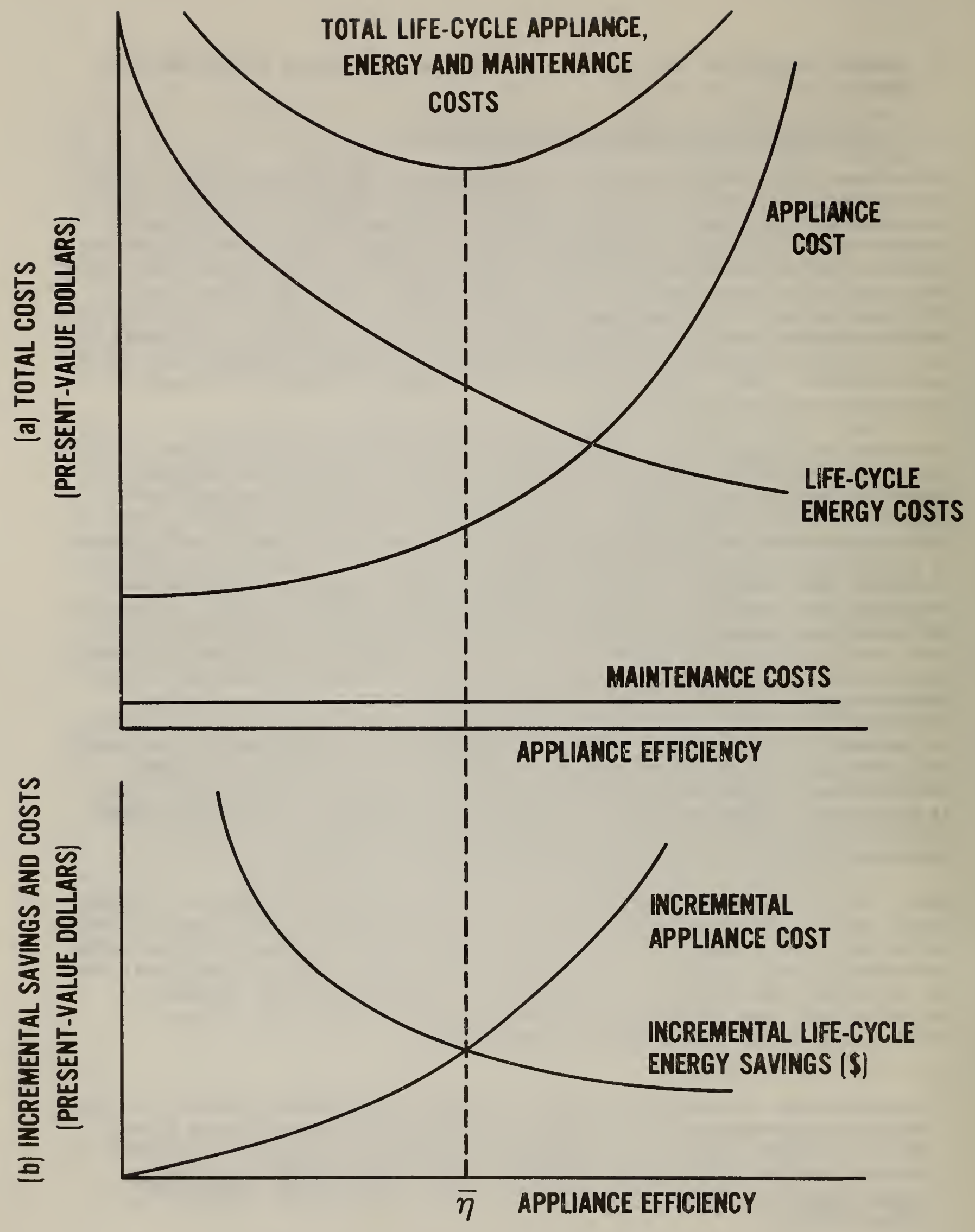

Figure 1. Life-Cycle Appliance-Related Costs 
At any point to the left of $\bar{\eta}$, an increase in appliance efficiency w111 result in incremental life-cycle savings greater than incremental costs; to the right of $\bar{n}$, an increase in efficiency will result in incremental costs greater than incremental savings. Thus the maximum cost-effective level of efficiency, again identified as $\bar{\eta}$, is achieved where incremental savings just equal incremental costs. Incremental savings and costs are used for identifying the economically optimal level of heat pump efficiency in this report because they are often more accurately estimated than total life-cycle savings and costs.

Projected life-cycle dollar savings will vary significantly with changes in assumptions related to projected energy prices, operational profile, useful lifetime, and discount rate. Each of these factors is therefore relevant in determining the optimal level of energy efficiency. Given a known useful appliance life and discount rate, an increase in energy prices or operating hours will shift the incremental savings curve to the right, increasing the optimal efficiency level. This is shown in figure 2, where a shift in the incremental savings curve from IS to IS' raises the optimal efficiency level from $\bar{n}$ to $\bar{n}^{\prime}$. Similarly, a decrease in energy prices or operating hours will shift the incremental savings curve to the left (IS"), with a corresponding decrease in the optimal efficiency level (to $\bar{\eta}^{\prime \prime}$ in figure 2).

\subsection{COMPUTATION OF INCREMENTAL SAVINGS AND COSTS FOR HEAT PUMP SYSTEMS}

The determination of an optimal efficiency level for a heat pump is somewhat more complicated than for most other appliances because its efficiency in the heating mode (HSPF) is measured differently than its efficiency in the cooling mode (SEER) ${ }^{1}$. While these different efficiency parameters are specified separately, they are functionally interdependent. (This interdependent relationship will be examined further in section 3.3.) While a composite annual efficiency measurement could be specified for a particular unit in a particular application, it would have little meaning in other applications since the ratio of heating requirements to cooling requirements is quite variable. As a result, there is little purpose in evaluating the annual efficiency of a heat pump system. Instead, the HSPF and SEER that can be economically justified for a given set of assumptions will be specified separately.

The reduction in annual heating energy use due to an increase in HSPF, from $\mathrm{HSPF}_{i-1}$ to $\mathrm{HSPF}_{i}$, can be calculated as follows:

$$
\Delta \mathrm{HEU}_{i}=\frac{\mathrm{AHR}\left(\mathrm{HSPF}_{i}-\mathrm{HSPF}_{i-1}\right)}{(3413)\left(\mathrm{HSPF}_{i}\right)\left(\mathrm{HSPF}_{i-1}\right)}
$$

1 HSPF is defined as the total heating season heat output in Btu divided by total heating season energy input in Btu $(3413 \mathrm{Btu}=1 \mathrm{kWh})$. SEER is defined as the total cooling season heat removed (in Btu) divided by total cooling season energy input in Wh. 


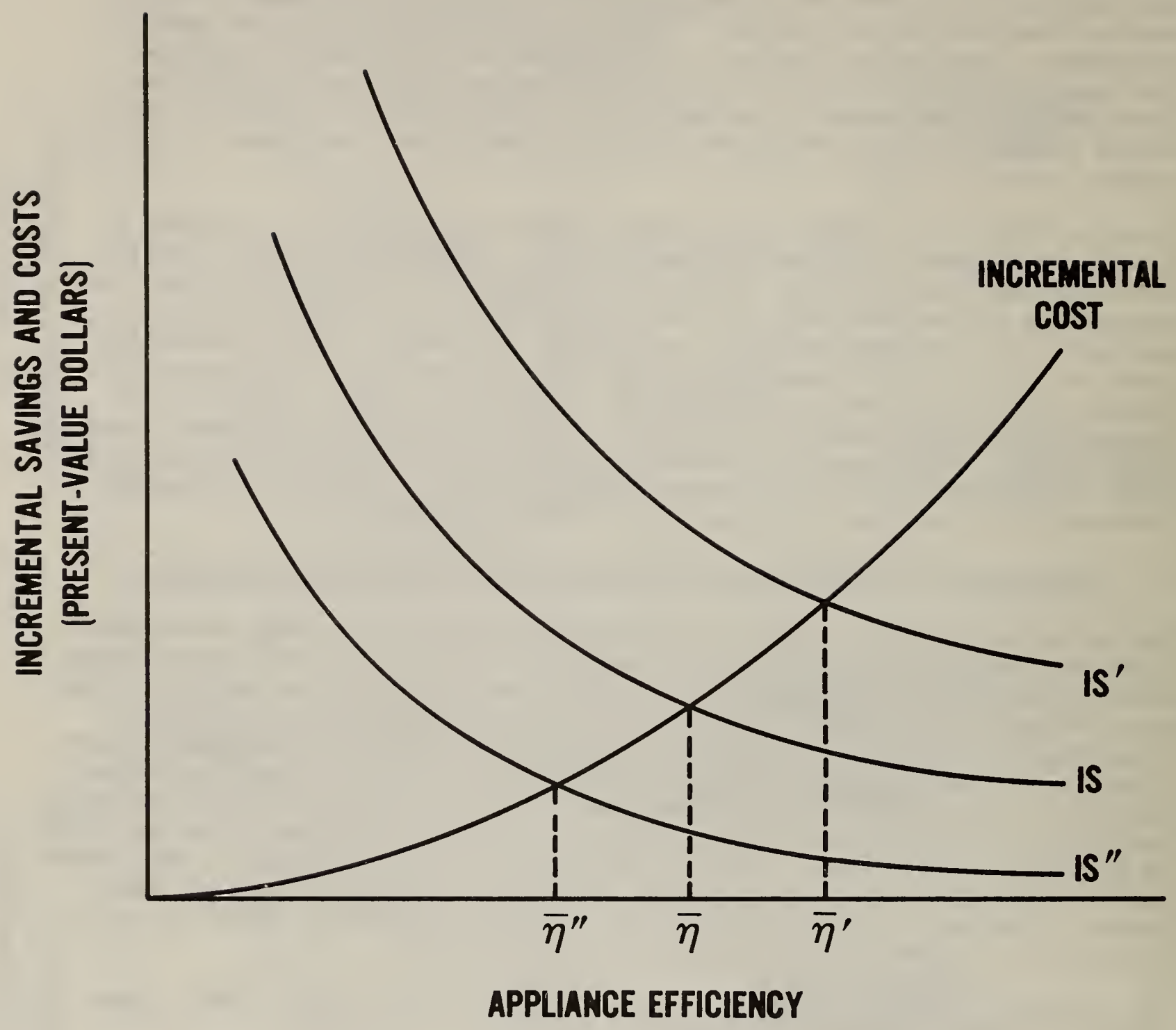

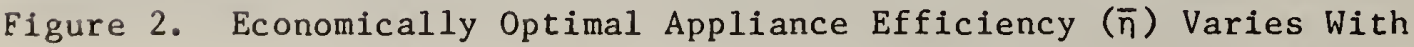
Assumptions Governing Incremental Dollar-Value Energy Savings (IS). 
where: $\Delta H \mathrm{U}_{\mathrm{i}}=$ reduction in annual heating energy use (in $\mathrm{kWh}$ ) due to an increase in $\mathrm{HSPF}$ from $\mathrm{HSPF}_{i-1}$ to $\mathrm{HSPF}_{i}$,

AHR = annual heating requirements in Btu, and

$3413=\mathrm{Btu}$ per $\mathrm{kWh}$.

The reduction in annual cooling energy requirements due to an increase in SEER, from SEER $_{i-1}$ to $\mathrm{SEER}_{i}$, can be calculated as:

$$
\Delta \operatorname{CEU}_{i}=\frac{\operatorname{ACR}\left(\operatorname{SEER}_{1}-\operatorname{SEER}_{i-1}\right)}{(1000)\left(\operatorname{SEER}_{i}\right)\left(\operatorname{SEER}_{i-1}\right)}
$$

where: $\Delta \mathrm{CEU}_{\mathrm{i}}=$ reduction in annual cooling energy requirements (in $\mathrm{kWh}$ ) due to an increase in SEER from SEER ${ }_{i-1}$ to $S_{E E R_{i}}$,

$\mathrm{ACR}=$ annual cooling requirements in $\mathrm{Btu}$, and

$1000=$ Watts per $\mathrm{kWh}$.

Annual energy savings $\left(\triangle \mathrm{AEU}_{i}\right)$ due to an increase in $\mathrm{HSPF}$ from $H S P F_{i-1}$ to HSPF $_{i}$ and a simultaneous increase in SEER from SEER fll $_{1}$ to SEER $_{\mathbf{i}}$ are therefore the sum of the seasonal energy savings, $i . e .$,

$$
\Delta \mathrm{AEU}_{i}=\Delta \mathrm{HEU}_{i}+\Delta \mathrm{CEU}_{i}
$$

Incremental present-value, life-cycle dollar savings (IS) corresponding to $\triangle \mathrm{AEU}_{1}$ can be calculated as:

$$
\text { IS }=\left(\Delta \mathrm{AEU}_{\mathrm{i}}\right)(\mathrm{P})(\mathrm{UPW}) \text {, }
$$

where: $\quad P=$ purchase price of energy in $\mathrm{kWh}$ at the beginning of the heat pump operating life, and UPW $^{*}=$ modified uniform present worth factor.

The modified uniform present worth factor is a function of the useful life of the system, the projected rate of $\mathrm{kWh}$ price increase, and the appropriate discount rate. Procedures for calculating UPW are discussed in Appendix A.

For an individual homeowner, the most appropriate price per $\mathrm{kWh}$ to use in an economic analysis is the marginal cost of the last $\mathrm{kWh}$ purchased. However, the appropriate price per kWh to be used in an analysis of an appliance for standards development purposes is better based on the cost of the new electrical generation and distribution capacity, since this is the energy that will actually be saved due to a large scale conservation effort. The Department of Energy has been estimating these costs and should soon be able to provide them for use in economic analyses supporting minimum standards development. Similarly, discount rates, projected rates of increase for $\mathrm{kWh}$ prices, and useful lifetime assessments should be consistent with the assumptions used in other analyses supporting DoE minimum efficiency standards for appliances and building energy standards.

As stated in section 2.1 , incremental costs include all costs incurred as a result of a given increase in HSPF or SEER. These incremental costs include not only any increase in purchase and installation costs, but any increase in maintenance and repair costs as well, discounted to present value. Most of the 
increase in heat pump cost due to improvements in efficiency are likely to be in the purchase cost. However, higher efficiency heat pump equipment may have slightly higher installation costs than lower efficiency equipment because it will typically have a larger outdoor condenser unit. Maintenance and repair costs are not likely to be significantly higher for higher efficiency heat pumps than lower efficiency heat pumps unless the compressor must be replaced. The expected occurrence of compressor replacement depends to some extent on the useful life assigned to the heat pump in the life-cycle cost analysis.

In the following section, a methodology for calculating the annual energy savings from improvements in heat pump design will be presented. Since these savings vary significantly by region, house design, and operational profile, a general methodology that can be used in establishing minimum heat pump efficiency standards is developed. 
3. CALCUlating the SEASONAL PER Formance OF heAT PUMPS IN THE heAT ING AND COOLING MODES

\subsection{COOLING MODE CALCULAT IONS}

The seasonal energy efficiency ratio (SEER) in $B t u / h$ output per Watt input (Btu/Wh) for a single-speed heat pump operating in the cooling mode is determined using the NBS testing and rating method. This method requires that the steady-state energy efficiency ratio of the heat pump at $82^{\circ} \mathrm{F}$ outdoor and $80^{\circ} \mathrm{F}$ indoor dry bulb temperature (EER 82 ) and a degradation coefficient for part-load performance due to cycling on and off $\left(C_{D}\right)$ be measured as prescribed by the test method. The SEER is then determined by the equation:

$$
\operatorname{SEER}=[\text { PLF }(0.5)]\left[E_{82}\right] \text {, }
$$

where:

$0.5=$ cooling load factor (i.e. the ratio of total cyclical cooling done during a complete cycle (including off-time) to steadystate cooling capacity over the same time period at the same ambient conditions),

PLF $(0.5)=$ the part-load factor for a cooling load factor of 0.5

$=1-C_{D}(1-0.5)$, and

EER $_{82}=$ (output capacity in Btu/h at $82^{\circ} \mathrm{F}$ ) $/\left(\right.$ power input in $\mathrm{W}$ at $82^{\circ} \mathrm{F}$ ).

A $C_{D}$ of 0.25 is assumed to be representative of heat pumps operating in the air conditioning mode, based on NBS testing.

It should be noted that this method for estimating SEER is not dependent on geographic region since average cooling temperatures tend to be reasonably similar in different regions of the United States. In addition, this method assumes that the heat pump is properly sized for the design cooling load ${ }^{3}$ in order to ensure proper dehumidification, and that cooling loads are proportional to $\left(t_{o}-65^{\circ} \mathrm{F}\right)$, where $t_{o}$ is the outdoor dry-bulb temperature. (This rating procedure thus assumes that natural ventilation is not used to any significant degree for cooling when the outdoor temperature is above $65^{\circ} \mathrm{F}$. )

1 G. Kelly and W. Parken, Method of Testing, Rating and Estimating the Seasonal Performance of Central Air-Conditioners.

2 Ibid.

3 Proper heat pump sizing is defined in the NBS testing and rating procedures to be 10 percent greater than the design hourly cooling load, the cooling load exceeded in only $21 / 2$ percent of all cooling hours. 
The Alr Conditioning and Refrigeration Institute (ARI) Directory ${ }^{1}$ regularly reports certain performance parameters for heat pumps manufactured in the United States. This Directory provides an important and extensive data base which will be referenced at several points in this report. At present, however, neither SEER nor EER82 are reported for heat pumps in the ARI Directory. Instead, the energy efficiency ratio measured at $95^{\circ} \mathrm{F}$ outdoor and $80^{\circ} \mathrm{F}$ indoor dry-bulb temperature (EER95) is reported. In order to maintain consistency with the data base in the ARI Directory, it was necessary to estimate EER 82 as a function of EER95.

The Ray W. Herrick Laboratories at Purdue University, under contract to ARI, have recently reported EER $_{95}$ and EER $_{82}$ for 148 central air conditioners, based on the DoE testing and rating procedures. ${ }^{2}$ Since the steady-state operation of a heat pump in the cooling mode is quite similar to that of a central air conditioner, this data base can provide the basis for determining a statistical relationship between these two performance parameters. Several alternative regression ( $i . e .$, least-squares) equations were analyzed in order to determine how well EER 82 could be estimated as a function of EER95. The following simple linear regression gave the best results:

$$
\mathrm{EER}_{82}=\underset{(4.38)}{0.8123}+\frac{1.0206 \mathrm{EER}_{95}}{(39.77)} \quad\left(\mathrm{R}^{2}=0.915\right)
$$

The $\mathrm{R}^{2}$ (or "coefficient of determination") of 0.915 means that 91.5 percent of the variation in the dependent variable (EER82 here) can be "explained" by the regression equation. The closer the $\mathrm{R}^{2}$ approaches 1.0 , the more completely the variation in the dependent variable is identified. The numbers in parentheses beneath the regression equation are t-ratios, which test the significance of each of the independent variables. A t-ratio greater than 2.33 is significant at the 99 percent confidence level; that is, the probability that the independent variable does not affect the dependent variable is less than one percent.

Since measured EER data are not generally available for heat pumps, this relationship will be used in the calculation of EER82 for the determination of SEER in this report.

1 Directory of Certified Unitary Air-Conditioners, Air-Source Unitary Heat Pumps, Sound-Rated Outdoor Unitary Equipment, and Central System Humidifiers, January 1 - June 30, 1980, Air-Conditioning and Refrigeration Institute, Arlington, Virginia, 1980 .

2 S. Thomas, D. Tree, and V. Goldschmidt, "A Study of the Prediction and Measurement of Air Conditioning System Seasonal Performance Characteristics Compilation of Data and Analysis of Test Procedure for SEER," Ray W. Herrick Laboratories, Purdue University, Lafayette, Ind., sponsored by the Air-Conditioning and Refrigeration Institute, 1979. 


\subsection{HEAT ING MODE CALCULATIONS}

The seasonal performance factor for heating (HSPF), in Btu output per equivalent Btu input $(1 \mathrm{Btu} / \mathrm{h}=0.293 \mathrm{~W})$, can be approximated by using the NBS method for testing and rating heat pumps in the heating mode. ${ }^{1}$ This method is more complex than the rating method for heat pumps in the cooling mode since the hourly outdoor temperature profile and the corresponding heating loads of the house must be considered. As a result, the HSPF varies significantly with geographic region, house design, and heat pump size.

The measured performance characteristics of a given heat pump model needed to calculate HSPF are the output capacity and power input at outdoor dry-bulb temperatures of $47^{\circ}, 35^{\circ}$, and $17^{\circ} \mathrm{F}$, plus a degradation coefficient for partload performance $\left(C_{D}\right)$. The capacity and power parameters are measured at an indoor temperature of $70^{\circ} \mathrm{F}$. Ideally, the hourly heating load of the house and the corresponding outdoor temperature are known for each hour of the heating season.

The output capacity corresponding to the outdoor temperature in any given hour is estimated by extrapolating below $17^{\circ} \mathrm{F}$ and above $45^{\circ} \mathrm{F}$, using a linear equation fitting published capacity measurements for $17^{\circ} \mathrm{F}$ and $47^{\circ} \mathrm{F}$. Between outdoor temperatures of $17^{\circ} \mathrm{F}$ and $45^{\circ} \mathrm{F}$, capacity is estimated using a linear equation fitting $17^{\circ} \mathrm{F}$ and $35^{\circ} \mathrm{F}$ in order to account for performance degradation due to frosting of the outdoor coils. Input power requirements corresponding to the outdoor temperatures are estimated using an equation fitting published power requirements measured at $17^{\circ} \mathrm{F}$ and $47^{\circ} \mathrm{F}$. Above $47^{\circ} \mathrm{F}$, power input is modified by a part-load factor calculated as a function of $C_{D}$ in order to model losses due to cycling.

Rather than using hourly load and temperature data for each hour in the heating season to estimate HSPF, the NBS method for testing and rating heat pumps divides the outdoor temperature profile into $5^{\circ} \mathrm{F}$ temperature "bins," starting at $65^{\circ} \mathrm{F}$. Hourly heating loads are assumed to be proportional to $\left(65-t_{j}\right)$, where $t_{j}$ is the representative (midpoint) outdoor temperature for each bin.

Each temperature bin is weighted as a percentage of the total number of heating hours in the heating season below $65^{\circ} \mathrm{F}$. These weights vary by geographic region. Table 1 shows the weights used for the six major U.S. heating climate regions used in the NBS heat pump testing and rating procedure.

Supplementary electric resistance heating is assumed to be used to maintain an indoor temperature of $70^{\circ} \mathrm{F}$ when the output capacity of the heat pump falls below the heating load of the house. Electrical input for the heat pump and supplementary heating system are integrated over the heating season, and the total input divided into the total coincident heating output (in consistent thermal units) to arrive at HSPF.

1 W. Parken, G. Kelly, and D. Didion, Method of Testing, Rating and Estimating the Heating Seasonal Performance of Heat Pumps. 
Table 1. Major Heating Climate Regions in the Continental U.S.A.a

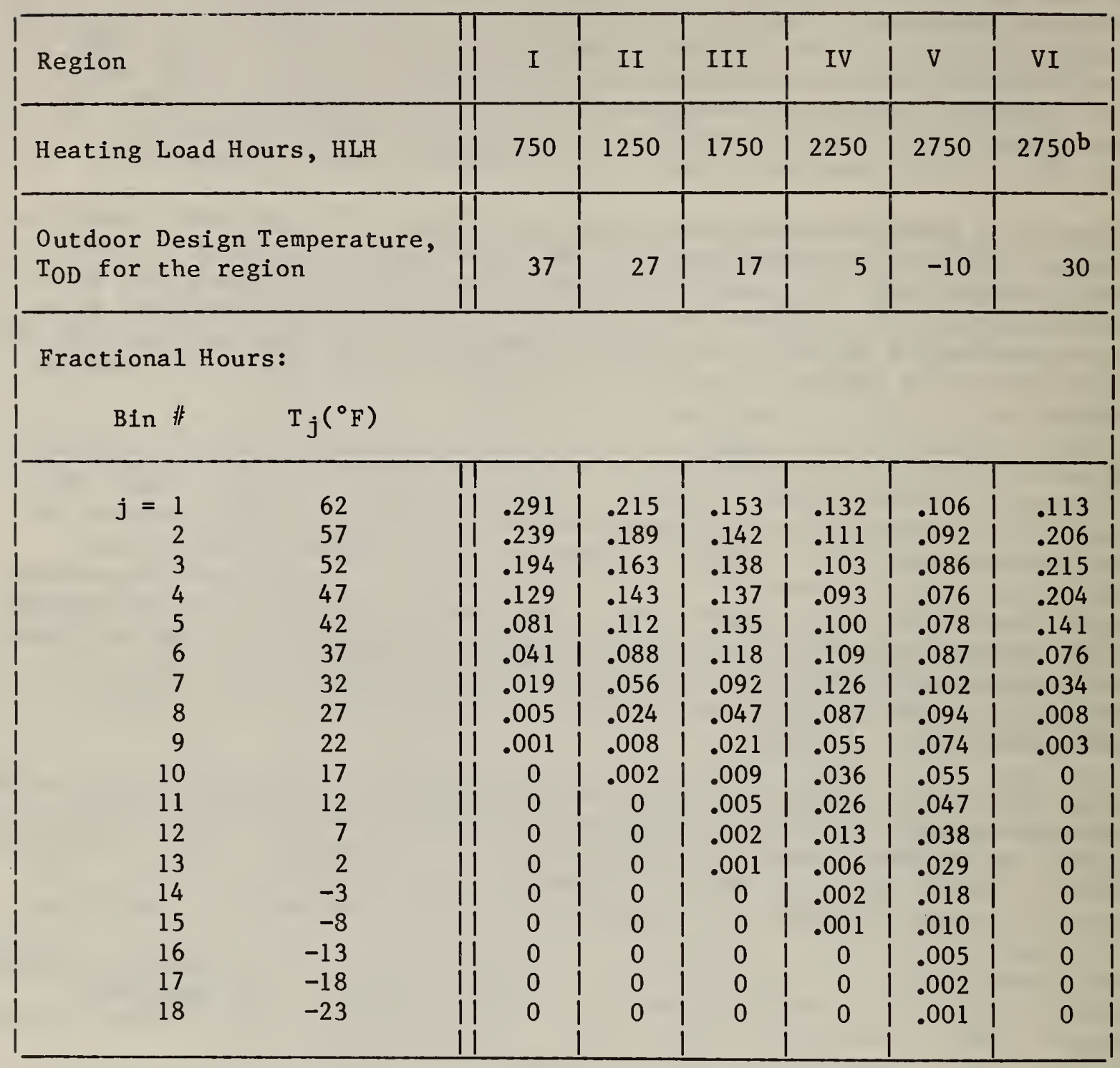

a Source: W. Parken, G. Kelly, and D. Didion, Method of Testing, Rating, and Estimating the Heating Seasonal Performance of Heat Pumps, p. 35 . See figure 3 for a map of the heating load hours in the United States.

b In Pacific Coast Region. 
Heat pump performance parameters (capacity and power) are both reported in the ARI Directory at $47^{\circ} \mathrm{F}$ and $17^{\circ} \mathrm{F}$ outdoor temperatures. The data in the Directory are used to provide consistency between estimates of the heating and cooling performance of heat pumps in this report. However, no measurements of capacity at $35^{\circ} \mathrm{F}$ outdoor temperature are reported. Since these are needed to calculate the capacity of a heat pump at outdoor temperatures between $17^{\circ} \mathrm{F}$ and $45^{\circ} \mathrm{F}$, this parameter must be estimated. This can be adequately performed by reducing the interpolated value for capacity at $35^{\circ} \mathrm{F}$ (Cap35) by a degradation coefficient due to coil frosting $\left(C_{F}\right)$; that is:

$$
\mathrm{Cap}_{35}=\left(0.4 \mathrm{Cap} 17+0.6 \mathrm{Cap}_{47}\right) \mathrm{C}_{\mathrm{F}} \text {. }
$$

The value for $C_{F}$ used in this report is $0.85^{1}$.

3.3 INTERRELATIONSHIP BETWEEN PERFORMANCE CHARACTERISTICS IN THE HEATING AND COOLING MODES

The purpose of this subsection is to develop an empirical model which quantifies the interrelationship between the steady-state performance characteristics of currently produced air-to-air residential heat pump systems in the heating and cooling modes. 2 A typical air-to-air heat pump system provides both space cooling and space heating functions using the same basic system components (an outdoor coil, compressor and fan, and an indoor coil and blower) in both operational modes. As a result, the steady-state performance characteristics (capacity and power) for the heating and cooling modes of a given heat pump design are closely related. It follows, therefore, that most modifications which increase heat pump efficiency in the cooling mode can be expected to result in increases in efficiency in the heating mode as wel1. 3

Since heat pumps are typically sized to match design cooling loads rather than design heating loads, the empirical model of heat pump performance developed in this report is based on performance characteristics measured in the cooling mode. For given increases in steady-state cooling efficiency, corresponding increases in steady-state heating efficiency are estimated. Based on the methodology outlined in subsections 3.1 and 3.2 , seasonal efficiency estimates can then be calculated in order to better determine corresponding reductions in annual energy usage.

1 Based on the NBS testing of heat pump systems.

2 It is important to note that the empirical model developed in this report is not meant to represent the theoretical relationship between heat pump performance in the heating and cooling modes and is therefore not necessarily valid in estimating the heating performance of new heat pump systems based on their cooling performance parameters.

3 Consideration of adequate dehumidification during the cooling cycle does place physical constraints on certain efficiency improvement options, notably on the indoor coil size. 
The ARI Directory lists several hundred outdoor heat pump units under 41 different trade names having cooling output capacity (rated at $95^{\circ} \mathrm{F}$ outdoor and $80^{\circ} \mathrm{F}$ indoor temperatures) in the range of 14,000 to $62,000 \mathrm{Btu} / \mathrm{h}$. These units have EER95 ratings ranging from 6.07 to $8.55 \mathrm{Btu} /$ Wh with a mean of 7.33 . Heating output capacities rated at $47^{\circ} \mathrm{F}$ and $17^{\circ} \mathrm{F}$ outdoor temperatures (at $70^{\circ} \mathrm{F}$ indoor temperature) are listed in the Directory for each unit. Power input requirements for each of these three ratings are also listed. No other rating points are published in the Directory.

The reported performance characteristics of each outdoor unit depend to some extent on the indoor coil size selected. For this report the indoor coil size which most closely matched the outdoor unit in output capacity was selected for each outdoor unit listed. The capacity and power measurements used in this report therefore correspond to this matched set of components. Variations in indoor coll size are not considered in this report because it is assumed that the indoor coil size is selected to properly match dehumidification requirements and indoor blower characteristics rather than to increase seasonal efficiency.

Close inspection of the Directory reveals that many of the models included are actually the same equipment, with only a difference in manufacturer name used for marketing purposes. All duplicate models that could be detected were eliminated, leaving a data base with 217 distinct models representing 24 different manufacturers. All models are air-to-air, split systems with single-speed compressors (ARI code HRCU-A-CB).

An initial plotting of the cooling capacities at $95^{\circ}$ and heating capacities at $47^{\circ} \mathrm{F}$ (Cap 95 and Cap 47, respectively) suggested that these two variables were linearly related. The least-squares linear regression equation that best fit this data is:

$$
\operatorname{Cap}_{47}(\mathrm{Btu} / \mathrm{h})=\underset{(3.0)}{-1,053.3+1.09364 \mathrm{Cap}_{95}(\mathrm{Btu} / \mathrm{h}) \cdot \quad(177.5)} \quad\left(\mathrm{R}^{2}=0.985\right)
$$

Alternative regression forms were examined. Since initial data plotting indicated that Cap 47 may be reduced slightly from the level predicted by equation (3.4) when EER95 (Cap95/Pow95) is greater than $7.0 \mathrm{Btu} / \mathrm{Wh}$, a multip le regression equation was calculated with both Cap95 and EER95 as independent variables. However, the inclusion of EER95 did not prove to be statistically significant $(t-r a t i o=0.33)$. As a result, equation $(3.4)$ is used to model Cap 47 as a function of Cap95. However, it should be noted that the highest EER95 in the data sample is $8.55 \mathrm{Btu} / \mathrm{Wh}$. Thus it is quite possible that for new units with EER95 greater than 8.55 Btu/Wh, EER95 may become a significant variable in determining Cap 47, and estimates of Cap 47 based on equation (3.4) may be overestimated for high efficiency units.

Similarly, regression equations were calculated to determine the functional relationship between power requirements at $95^{\circ} \mathrm{F}$ and $47^{\circ} \mathrm{F}$ (Pow95 and Pow 47 , respectively). Initial data plotting indicated that Pow 95 and Pow47 are also linearly related, but that EER95 may also explain some of the variation. 
Several multiple-variable regression equations were calculated. The best of these is:

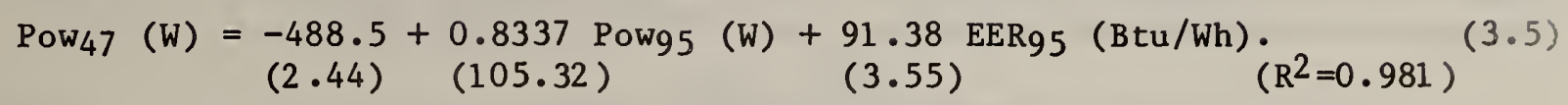

Note that in this case, Pow47 is shown to be partially dependent on the efficiency of the heat pump in the cooling mode (EER95). Each independent variable is shown to be statistically significant at the 99 percent confidence level and thus is included in the empirical model developed here.

Equations (3.4) and (3.5) can be used to calculate the degree to which steadystate heat pump efficiency in the heating mode varies with a given change in steady-state efficiency in the cooling mode. As an example, consider a 0.5 $\mathrm{Btu} /$ Wh imp rovement in EER95, from 8.0 to $8.5 \mathrm{Btu} / \mathrm{Wh}$, for a heat pump with a Cap 95 of $24,000 \mathrm{Btu} / \mathrm{h}$. First, calculate the input power in $\mathrm{W}$ before and after improvement (Pow95 and Pow'95, respectively):

$$
\begin{aligned}
& \text { Pow }_{95}=\frac{24,000 \mathrm{Btu} / \mathrm{h}}{8.0 \mathrm{Btu} / \mathrm{Wh}}=3,000 \mathrm{~W} \text {, and } \\
& \text { Pow' }_{95}=\frac{24,000 \mathrm{Btu} / \mathrm{h}}{8.5 \mathrm{Btu} / \mathrm{Wh}}=2,824 \mathrm{~W} .
\end{aligned}
$$

Using equation ( 3.4 ), the capacity of the heat pump at $47^{\circ} \mathrm{F}$ can be calculated based on its capacity at $95^{\circ} \mathrm{F}$ :

$$
\text { Cap } 47=-1053 \cdot 3+1.09364(24,000)=25,194 \mathrm{Btu} / \mathrm{h} .
$$

This is assumed to be held constant as the $E_{42} 7$ increases. Using equation (3.5), the power input can be calculated before and after the improvement in EER95 (Pow47 and Pow'47, respectively):

$$
\begin{aligned}
& \text { Pow }_{47}=-488.5+0.8337(3,000)+91.38(8.0)=2743.6 \mathrm{~W} \text {, and } \\
& \text { Pow' } 47=-488.5+0.8337(2,824)+91.38(8.5)=2642.6 \mathrm{~W} \text {. }
\end{aligned}
$$

Now calculate the steady-state efficiency of the heat pump at $47^{\circ} \mathrm{F}$ before and after the increase in efficiency at $95^{\circ} \mathrm{F}$ (EER 47 and EER' 47 , respectively):

$$
\begin{aligned}
& \operatorname{EER}_{47}=(25,194 \mathrm{Btu} / \mathrm{h}) / 2743.6 \mathrm{~W}=9.18 \mathrm{Btu} / \mathrm{Wh} \text {, and } \\
& \mathrm{EER}^{\prime} 47=(25,194 \mathrm{Btu} / \mathrm{h}) / 2642.6 \mathrm{~W}=9.53 \mathrm{Btu} / \mathrm{Wh} \text {. }
\end{aligned}
$$

Thus the $0.5 \mathrm{Btu} /$ Wh increase in steady-state efficiency at $95^{\circ} \mathrm{F}$ (EER95) corresponds to a $0.35 \mathrm{Btu} / \mathrm{Wh}$ increase in steady-state efficiency at $47^{\circ} \mathrm{F}$ $\left(E_{47}\right)$ or an equivalent increase in steady-state coefficient of performance of 0.10 Btu output/Btu input at $47^{\circ} \mathrm{F}\left(\mathrm{COP}_{47}\right)$.

As a check on the accuracy of the estimates obtained from equations ( 3.4 ) and (3.5), a comparison was made of the published ratings in the ARI Directory 
with the predicted values for capacity and power and the corresponding COP based on those equations. The absolute percentage difference (\% DIFF) between the actual value (ACT) and the predicted value (PRED), calculated from the corresponding regression equation, was computed as follows:

$$
\% \mathrm{DIFF}=\frac{\mathrm{ACT}-\mathrm{PRED}}{\mathrm{ACT}} \times 100
$$

The percentage was determined for each of the three variables for all 217 heat pump units in the sample. The mean absolute percent error ${ }^{1}$ was then calculated for each variable as follows:

\begin{tabular}{lr} 
Variable & Mean Absolute Perc \\
\cline { 2 - 2 } Cap47 & $3.44 \%$ \\
P ow47 & $3.73 \%$ \\
COP 47 & $3.61 \%$
\end{tabular}

Equations (3.4) and (3.5) establish a statistical model of steady-state heat pump performance at $47^{\circ} \mathrm{F}$, based on its performance at $95^{\circ} \mathrm{F}$. However, in order to estimate the seasonal efficiency of a heat pump system, the output capacity and power input at $17^{\circ} \mathrm{F}$ outdoor temperature ( $\mathrm{Cap}_{17}$ and $\mathrm{P}_{\text {ow }} 17$ ) are also needed. The same approach described above was taken, using the same 217 outdoor heat pump units in the ARI Directory.

As might be expected, it was found that $\mathrm{Cap}_{47} 7$ and $\mathrm{P}$ ow 47 were better predictors of Cap17 and Pow17 than Cap95 and Pow95 The equation which bests fits the heating capacity data is:

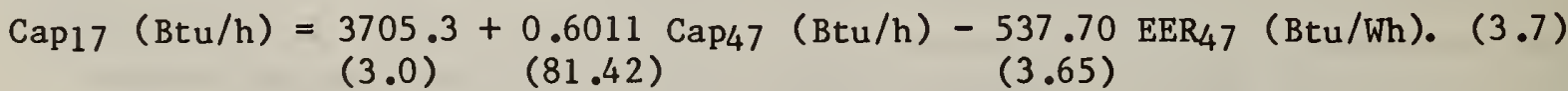

$$
\begin{aligned}
& \left(R^{2}=0.972\right)
\end{aligned}
$$

The $\mathrm{R}^{2}$ for this equation again indicates a highly satisfactory explanation of the variation in the independent value. Note that in this case the estimate of Cap 17 is reduced as EER 47 is increased. This has important consequences in the seasonal efficiency calculation because it means that more supplementary heat will be needed at the lower outdoor temperatures, offsetting some of the increase in EER in the heating mode.

1 For a description of the use of mean absolute percent error and similar quantities to test the performance of a simulation model, see Section 10.2 of R. Pindyke and D. Rubinfeld, Econometric Models and Economic Forecasts, McGraw-Hill Book Company, New York, 1976.

2 In addition, the heating output capacity at $35^{\circ} \mathrm{F}$ is also needed. However, this parameter is not published in the ARI Directory. Estimation of this parameter is discussed in section 3.4 . 
The equation which best fits input power data is:

$$
\begin{aligned}
\text { Pow }_{17}(W)= & 206.0+0.8287 \text { Pow }_{47}(W) \quad(4.98) \quad(103.64)
\end{aligned} \quad\left(R^{2}=0.980\right)
$$

When EER 47 was introduced as an independent variable in the regression analysis, it was found to be statistically insignificant in this case (t-ratio $=0.89$ ). However the negative coefficients estimated for EER 47 in this case implies that it may tend to reduce Pow 17 slightly.

The mean absolute percent error between the calculated and actual values for Cap 17, Pow 17 and $\mathrm{COP}_{17}$ were computed as follows:

\begin{tabular}{lr} 
Variable & Mean Absolute Perce \\
\cline { 2 - 2 } & $5.26 \%$ \\
Cap $_{17}$ & $4.47 \%$ \\
COP $_{17}$ & $5.99 \%$
\end{tabular}

It was shown above that a $0.5 \mathrm{Btu} /$ Wh increase in EER95 results in an 0.35 $\mathrm{Btu} /$ Wh increase in EER 47. This can be extended to show the effect of this change on $\mathrm{EER}_{17}\left(\mathrm{Cap}_{17} / \mathrm{Pow}_{17}\right.$ ) and the corresponding $\mathrm{COP}_{17}$.

Using equation ( 3.7 ), the heat pump output capacity at $17^{\circ} \mathrm{F}$, before and after the imp rovement in EER95 ( $\mathrm{Cap}_{17}$ and Cap'17, respectively), can be calculated based on Cap 47 and EER 47 :

$$
\begin{aligned}
& \operatorname{Cap}_{17}=3705.3+0.6011(25,194)-537.7(9.18)=13913.3 \mathrm{Btu} / \mathrm{h} \text {, and } \\
& \text { Cap }^{\prime} 17=3705.3+0.6011(25,194)-537.7(9.53)=13725.1 \mathrm{Btu} / \mathrm{h} \text {. }
\end{aligned}
$$

Using equation (3.8), the power input at $17^{\circ} \mathrm{F}$ (Pow 17 and Pow' 17 ) can be calculated based on Pow47 and Pow'47, respectively:

$$
\begin{aligned}
& \text { Pow }_{17}=206.0+0.8287(2743.6)=2479.6 \mathrm{~W}, \text { and } \\
& \text { Pow'17 }_{17}=206.0+0.8287(2642.6)=2395.9 \mathrm{~W} .
\end{aligned}
$$

Now the steady-state efficiency of the heat pump at $17^{\circ} \mathrm{F}$ before and after the increase in efficiency at $95^{\circ} \mathrm{F}\left(E R_{17}\right.$ and EER' 17 , respectively) can be calculated:

$$
\begin{aligned}
& \operatorname{EER}_{17}=(13913.3 \mathrm{Btu} / \mathrm{h}) / 2479.6 \mathrm{~W}=5.61 \mathrm{Btu} / \mathrm{Wh} \text {, and } \\
& \text { EER' }_{17}=(13725.1 \mathrm{Btu} / \mathrm{h}) / 2395.9 \mathrm{~W}=5.73 \mathrm{Btu} / \mathrm{Wh} \text {. }
\end{aligned}
$$

Note that an increase of $0.5 \mathrm{Btu} / \mathrm{Wh}$ in EER95 and the corresponding 0.35 $\mathrm{Btu} /$ Wh increase in EER 47 results in $0.12 \mathrm{Btu} /$ Wh increase in $\mathrm{EER}_{17}$, or a 0.035 Btu output/Btu input increase in the coefficient of performance at $17^{\circ} \mathrm{F}\left(\mathrm{COP}_{17}\right)$. 
3.4 INTERRELAT IONSHIP BETWEEN SEASONAL PERFORMANCE CHARACTERISTICS IN THE HEAT ING AND COOLING MODES

Using the methods for calculating seasonal energy performance for cooling (SEER) and heating (HSPF) outlined in sections 3.1 and 3.2 , and the functional relationships shown between the steady-state capacity and power performance characteristics in section 3.3 , the HSPF corresponding to any given SEER can be estimated for a given heat pump size in a given building located in a specified climate region. However, since the highest EER95 for any residential, air-to-air base heat pump system listed in the ARI Directory is $8.55 \mathrm{Btu} / \mathrm{Wh}$ (SEER $\cong 8.4 \mathrm{Btu} / \mathrm{Wh}$ ), any estimate of HSPF corresponding to an SEER greater than approximately 8.5 is based on extrapolation.

Since a heat pump is typically sized to match design cooling loads rather than heating loads, and since there is no general relationship between heating loads and cooling loads in houses, it is impossible to calculate an HSPF corresponding to a given SEER without specification of both the climate profile and the corresponding building heating loads. Six major U.S. heating climate regions are defined in the NBS heat pump testing and rating procedure. The heating load hours, outdoor design temperatures, and fractional hours for each of the $5^{\circ} \mathrm{F}$ temperature bins used in the calculation procedure are shown in table 1 for each of these six regions.

As explained in subsection 3.1 , the SEER of a given heat pump, properly sized for the air conditioning loads of a house, is assumed to be the same in all regions of the country. However, in each climate region shown in table 1 , the HSPF corresponding to a given SEER and change in HSPF corresponding to a given change in SEER, will be different. Table 2 shows the HSPF corresponding to nine levels of SEER, in $0.5 \mathrm{Btu} / \mathrm{Wh}$ increments from 7.0 to $11.0 \mathrm{Btu} / \mathrm{Wh}$, for the six climate regions indicated, based on a $24,000 \mathrm{Btu} / \mathrm{h}$ (Cap95) heat pump. It is important to note that a $0.5 \mathrm{Btu} / \mathrm{Wh}$ increase in SEER (equivalent to a 0.56 $\mathrm{Btu} / \mathrm{Wh}$ increase in EER95) from 8.0 to $8.5 \mathrm{Btu} / \mathrm{Wh}$ results in increases in HSPF ranging from $0.087 \mathrm{Btu}$ output/Btu input $(0.300 \mathrm{Btu} / \mathrm{Wh}$ ) in region I (the warmest region) to $0.024 \mathrm{Btu}$ output/Btu input $(0.082 \mathrm{Btu} / \mathrm{Wh}$ ) in region $\mathrm{V}$ (the coldest region). It is apparent that improvements in a heat pump design that increase its overall performance will have significantly more effect on seasonal cooling performance than seasonal heating performance, especially in the colder climates. As a result, the greatest potential energy savings due to improvements on heat pump design are likely to occur in houses where annual cooling requirements clearly dominate annual heating requirements. (This is, of course, most likely to occur in southern climates.)

The design heating loads (DHL) shown in table 2 correspond to the midpoint between the minimum and maximum design heating loads as defined in the NBS testing and rating methodology. 1 (It will be shown in section 4.2 that the midpoint provides a reasonable estimate of design loads in certain cases.) As noted above, the increase in HSPF due to a $0.5 \mathrm{Btu} / \mathrm{Wh}$ improvement is not only a function of climate but of the size of the design heating load relative to the output capacity of the heat pump at that same temperature. Tables 3 and 4 show the HSPF of a heat pump corresponding to the same nine levels of SEER in the same six climate regions as table 2, but in this case the design heating 
Table 2. HSPF by Heating Climate Region:a $24,000 \mathrm{Btu} / \mathrm{h}$ Capacity $\left(95^{\circ} \mathrm{F}\right)$, Midpoint DHL

\begin{tabular}{|c|c|c|c|c|c|c|c|}
\hline \multicolumn{2}{|c|}{ Heating Climate Region } & I & II & III & IV & $\mathrm{v}$ & VI \\
\hline \multicolumn{2}{|c|}{$\begin{array}{l}\text { Design Heating Load } \\
\qquad(\mathrm{kBtu} / \mathrm{h})\end{array}$} & II 17.6 & 23.9 & 30.2 & 37.8 & 40.3 & 22.0 \\
\hline \multicolumn{2}{|c|}{$\begin{array}{c}\text { Annual Heating } \\
\text { Requirements } \\
\left(10^{6} \mathrm{Btu} / \mathrm{yr}\right)\end{array}$} & II 10.19 & 23.03 & 40.73 & 65.47 & 85.34 & 46.68 \\
\hline $\begin{array}{c}\text { SEER } \\
(\mathrm{Btu} / \mathrm{Wh})\end{array}$ & $\begin{array}{l}\text { EER95 } \\
(\mathrm{Btu} / \mathrm{Wh})\end{array}$ & \multicolumn{6}{|c|}{ HSP F } \\
\hline $\begin{array}{l}7.0 \\
7.5 \\
8.0 \\
8.5\end{array}$ & $\begin{array}{l}7.04 \\
7.60 \\
8.16 \\
8.72\end{array}$ & $\begin{array}{ll}\| & 1.948 \\
\| & 2.056 \\
\| & 2.153 \\
\| & 2.240\end{array}$ & $\begin{array}{l}1.862 \\
1.958 \\
2.043 \\
2.118\end{array}$ & $\begin{array}{l}1.773 \\
1.854 \\
1.925 \\
1.987\end{array}$ & $\begin{array}{l}1.612 \\
1.666 \\
1.712 \\
1.750\end{array}$ & $\begin{array}{l}1.453 \\
1.488 \\
1.517 \\
1.541\end{array}$ & $\begin{array}{l}1.904 \\
2.007 \\
2.099 \\
2.182\end{array}$ \\
\hline $\begin{array}{r}9.0 \\
9.5 \\
10.0 \\
10.5 \\
11.0\end{array}$ & $\begin{array}{r}9.28 \\
9.84 \\
10.40 \\
10.96 \\
11.52\end{array}$ & $\begin{cases}\mid 1 & 2.316 \\
\| & 2.383 \\
\| & 2.440 \\
\| & 2.489 \\
11 & 2.529\end{cases}$ & $\begin{array}{l}2.184 \\
2.241 \\
2.290 \\
2.331 \\
2.364\end{array}$ & $\begin{array}{l}2.041 \\
2.087 \\
2.126 \\
2.158 \\
2.184\end{array}$ & $\begin{array}{l}1.783 \\
1.810 \\
1.832 \\
1.850 \\
1.864\end{array}$ & $\begin{array}{l}1.560 \\
1.575 \\
1.586 \\
1.596 \\
1.603\end{array}$ & $\begin{array}{l}2.255 \\
2.318 \\
2.372 \\
2.418 \\
2.455\end{array}$ \\
\hline
\end{tabular}

a Calculated using methodology described in section 2 .

b Calculations of HSPF's corresponding to given SEER's are based on statistical relationships that were estimated from a data base with no observed SEER greater than $8.55 \mathrm{Btu} / \mathrm{Wh}$. Thus any HSPF below this line is extrapolated from the data base. 
loads are those corresponding to the minimum and maximum, respectively, defined in the NBS testing and rating methodology. Table 3 shows that while the HSPF corresponding to a given SEER is smaller than those in table 2 , the increase in $\mathrm{HSPF}$ due to a $0.5 \mathrm{Btu} / \mathrm{Wh}$ increase in SEER tends to be slightly larger (except in climate regions $\mathrm{I}$ and VI). Table 4 generally shows the opposite results, except that the increase in HSPF tends to be slightly smaller than those in table 2 in all regions. The smallest increase in HSPF is in climate region $\mathrm{V}$ for the case with the maximum design heating loads: an increase in SEER from 8.0 to $8.5 \mathrm{Btu} / \mathrm{Wh}$ results in a $0.016 \mathrm{Btu}$ output/Btu input increase in HSPF $(0.055 \mathrm{Btu} / \mathrm{Wh})$. The largest increase in HSPF due to an increase in SEER from 8.0 to $8.5 \mathrm{Btu} / \mathrm{Wh}$ is in climate region $\mathrm{I}$ with the midpoint design heating loads: $0.087 \mathrm{Btu}$ output/Btu input $(0.30 \mathrm{Btu} / \mathrm{Wh})$. At the same time, it must be recognized that the annual heating requirements in climate region $I$ are typically so small that the increase in $\mathrm{HSPF}$ in this region will result in relatively little actual energy savings.

This same procedure was used to estimate the HSPF corresponding to the same SEER levels for three additional heat pump sizes. Tables 5, 6, and 7 show the HSPF's corresponding to unit capacities of $18,000,36,000$, and $48,000 \mathrm{Btu} / \mathrm{h}$ (Cap95), respectively. In all three cases the midpoint design heating loads were used. Note that the increase in HSPF due to a $0.5 \mathrm{Btu} / \mathrm{Wh}$ increase in SEER (from 8.0 to $8.5 \mathrm{Btu} / \mathrm{Wh}$ ) increases significantly as the output capacity is increased. For example, in climate region III, this increase in HSPF is 0.046 Btu output/Btu input $(0.16 \mathrm{Btu} / \mathrm{Wh})$ for the $18,000 \mathrm{Btu} / \mathrm{h}$ heat pump, but 0.094 Btu output/Btu input $(0.32 \mathrm{Btu} / \mathrm{Wh})$ for the $48,000 \mathrm{Btu} / \mathrm{h}$ heat pump. This is because the steady-state performance characteristics of the heat pump in the heating mode, as modeled empirically in section 3.3 , improve as Cap95 is increased.

Since the energy savings are related to the increase in HSPF, this relationship between capacity and increase in HSPF may be a significant factor in determining optimal heat pump efficiencies. It implies that for larger size heat pumps higher efficiency levels (both steady-state and seasonal) will be more readily economically justified than those for smaller size heat pumps. However, additional factors must be considered before this can be verified: the size of the annual heating and cooling requirements expected to be encountered and the relative cost of the improvements in efficiency for larger units compared to smaller units. In the next section, annual heating and cooling requirements will be estimated and projected energy savings will be calculated.

1 The DHL is assumed to be a function of the heat pump heating capacity at $47^{\circ} \mathrm{F}$ (Cap47) in the NBS methodology:

Minimum DHL $=\left(\mathrm{Cap}_{47}\right)\left(65^{\circ} \mathrm{F}-\mathrm{T}_{\mathrm{OD}}\right) / 60$

Minimum DHL $=$ Cap47

Maximum DHL $=(2)\left(\mathrm{Cap}_{47}\right)\left(65^{\circ} \mathrm{F}-\mathrm{T}_{\mathrm{OD}}\right) / 60$

Maximum DHL $=(2.2)(\mathrm{Cap} 47)$ for regions I,II, III, IV and VI.

for region $V$.

for regions $I, I I, I I I, I V$ and VI.

for region $\mathrm{V}$ 
Table 3. HSPF by Heating Climate Region: ${ }^{a} 24,000 \mathrm{Btu} / \mathrm{h}$ Capacity $\left(95^{\circ} \mathrm{F}\right)$, Minimum DHL

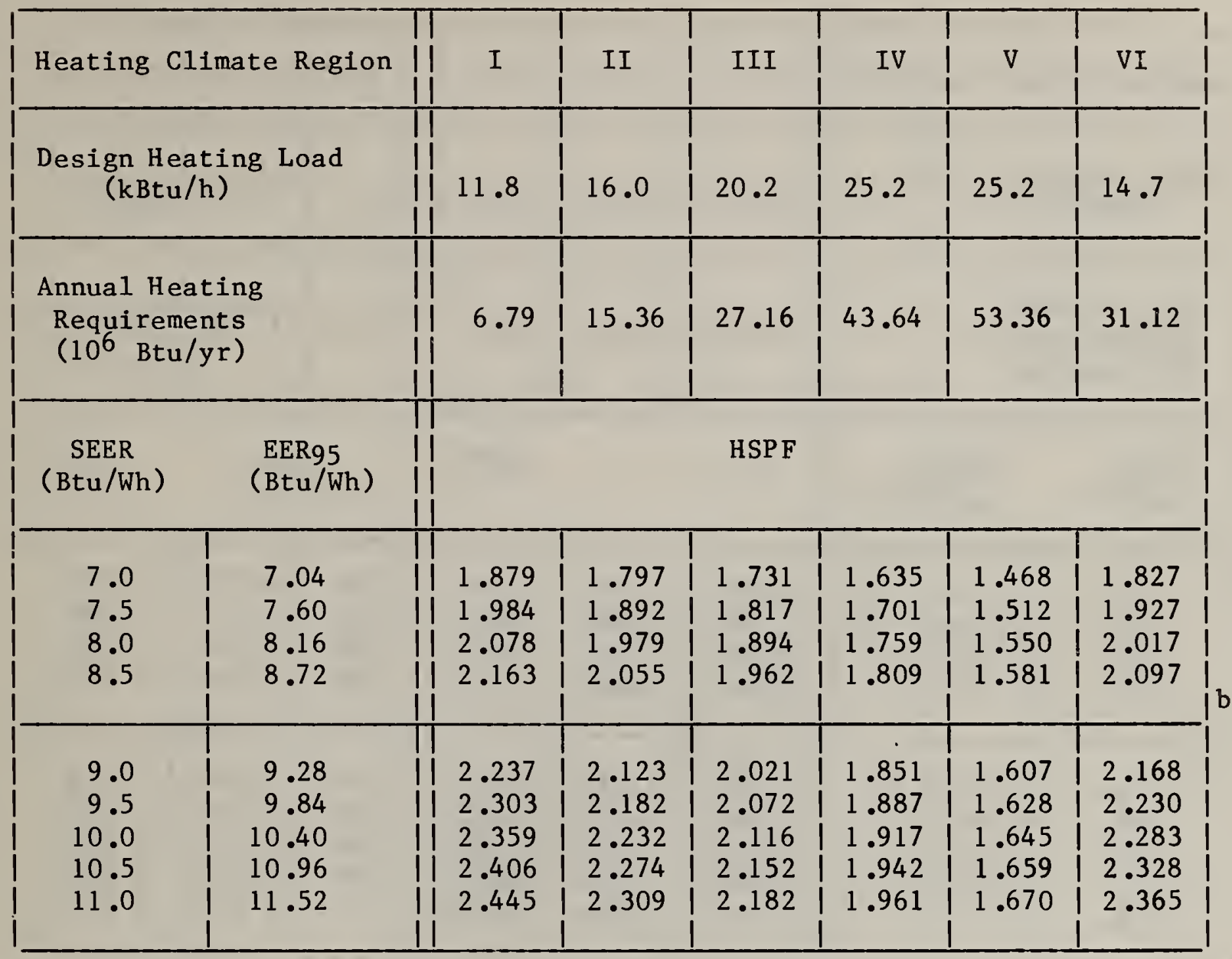

a Calculated using methodology described in section 2 .

b Calculations of HSPF's corresponding to given SEER's are based on statistical relationships that were estimated from a data base with no observed SEER greater than $8.55 \mathrm{Btu} / \mathrm{Wh}$. Thus any HSPF below this line is extrapolated from the data base. 
Table 4. HSPF by Heating Climate Region: ${ }^{a} 24,000 \mathrm{Btu} / \mathrm{h}$ Capacity $\left(95^{\circ} \mathrm{F}\right)$, Maximum DHL

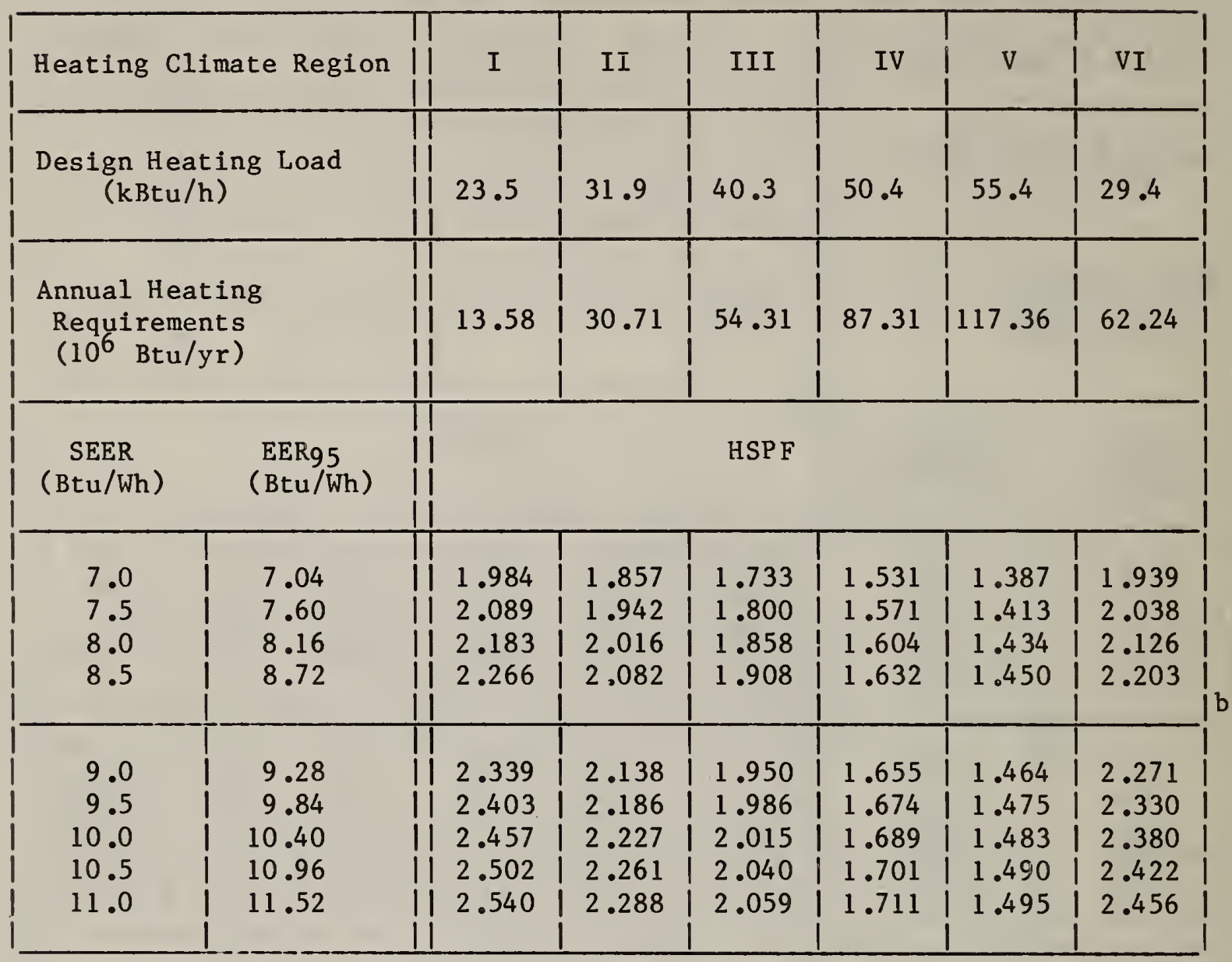

a Calculated using methodology described in section 2 .

b Calculations of HSPF's corresponding to given SEER's are based on statistical relationships that were estimated from a data base with no observed SEER greater than $8.55 \mathrm{Btu} / \mathrm{Wh}$. Thus any HSPF below this line is extrapolated from the data base. 
Table 5. HSPF by Heating Climate Region: ${ }^{a} 18,000 \mathrm{Btu} / \mathrm{h}$ Capacity $\left(95^{\circ} \mathrm{F}\right)$, Midpoint DHL

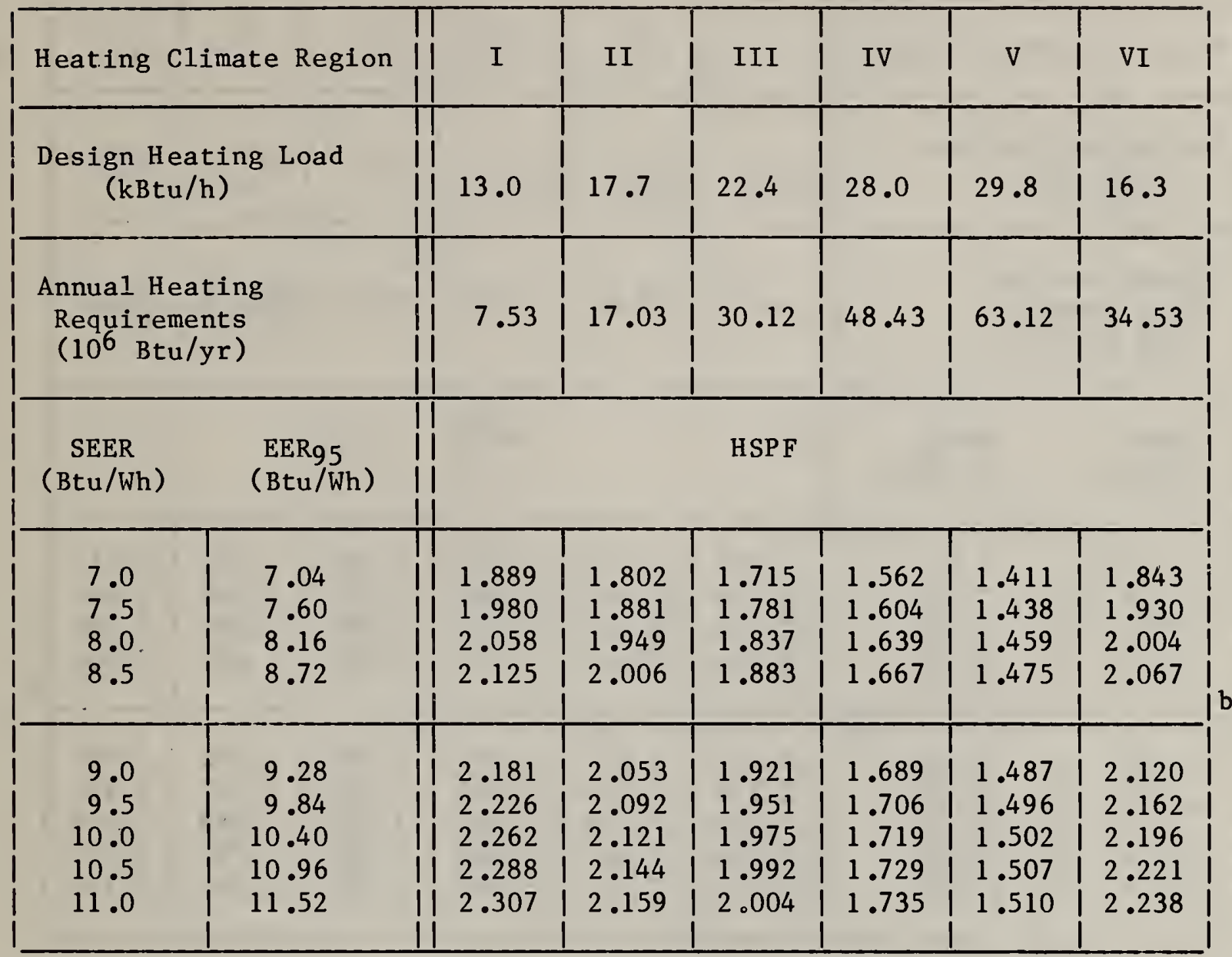

a Calculated using methodology described in section 2 .

b Calculations of HSPF's corresponding to given SEER's are based on statistical relationships that were estimated from a data base with no observed SEER greater than $8.55 \mathrm{Btu} / \mathrm{Wh}$. Thus any HSPF below this line is extrapolated from the data base. 
Table 6. HSPF by Heating Climate Region: ${ }^{\mathrm{a}} 36,000 \mathrm{Btu} / \mathrm{h}$ Capacity $\left(95^{\circ} \mathrm{F}\right)$, Midpoint DHL

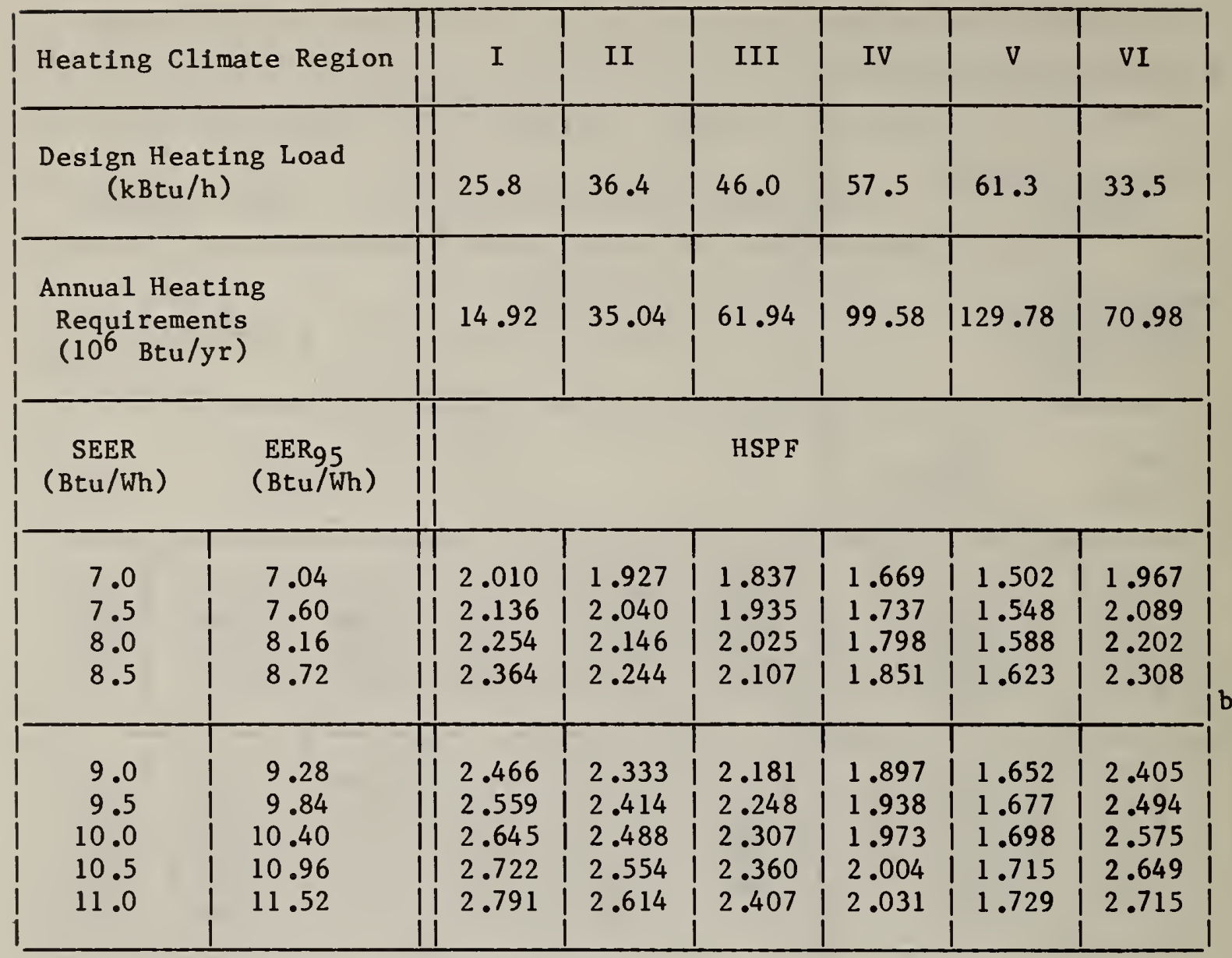

a Calculated using methodology described in section 2 .

b Calculations of HSPF's corresponding to given SEER's are based on statistical relationships that were estimated from a data base with no observed SEER greater than $8.55 \mathrm{Btu} / \mathrm{Wh}$. Thus any HSPF below this line is extrapolated from the data base. 
Table 7. HSPF by Heating Climate Region:a 48,000 Btu/h Capacity $\left(95^{\circ} \mathrm{F}\right)$, Midpoint DHL

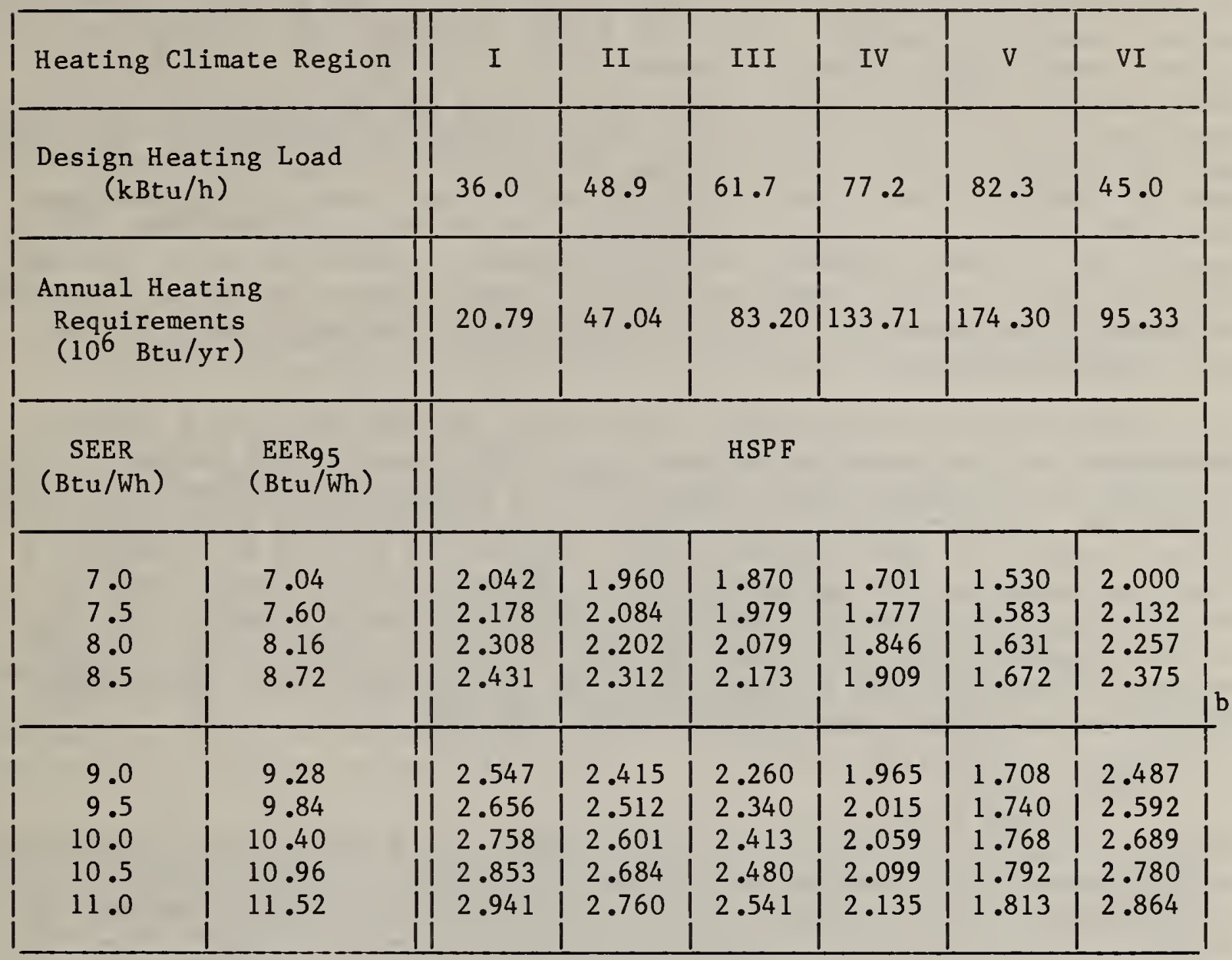

a Calculated using methodology described in section 2 .

b Calculations of HSPF's corresponding to given SEER's are based on statistical relationships that were estimated from a data base with no observed SEER greater than $8.55 \mathrm{Btu} / \mathrm{Wh}$. Thus any HSPF below this line is extrapolated from the data base. 


\section{ESTIMATING ANNUAL ENERGY SAVINGS}

In order to estimate the annual energy usage of a heat pump, estimates of the annual heating and cooling requirements (AHR, ACR) of the house in which it is to be installed are needed. These two design variables can be calculated for a given house using any one of a number of load determination programs (e.g. BLAST, DOE-2, NBSLD), representative climate data and an operational profile. Equations (2.1), (2.2), and (2.3) provide a calculation methodology that can be used to estimate annual energy savings attributable to given improvements in HSPF and SEER once the values of the AHR and ACR are known for a given house. These AHR and ACR are thermally independent of the type and efficiency of the heating and cooling equipment installed. However, typical values of AHR and ACR associated with heat pumps of different output capacities are not available to serve as the basis for estimating typical energy savings from increased heat pump efficiency.

As an alternative to typical AHR and ACR data, the NBS testing and rating procedures for heat pumps can be used to provide a generalized method for estimating AHR and ACR in different regions of the United States, based on the size of the heat pump installed rather than for specific building designs and operational parameters. This general method, examined in section 4.1, provides a good starting point for the estimation of annual heat pump energy usage and potential savings. However, these estimates appear to be somewhat high for the more tightly constructed housing that is likely to be built in the years to come. Thus a further analysis, based on DoE Building Energy Performance Standards (BEPS) data, is presented in section 4.2.

\subsection{GENERAL METHOD}

The NBS procedures for testing, rating and estimating the seasonal performance of heat pumps in the heating and cooling modes provide a general method for estimating the annual energy usage of a heat pump and the energy savings due to specified improvements in its steady-state efficiency ratings. Since the energy usage and energy savings will vary with the local climate profile, the annual heating and cooling requirements (AHR, ACR), and the design heating load (DHL) of a house, these must be specified as well.

Based on the general method for calculating heat pump energy utilization in the heating mode, AHR can be calculated using:

$$
\mathrm{AHR}=(\mathrm{DHL})(\mathrm{C})(\mathrm{HLH}) \text {, }
$$

where:

DHL = the design heating load of a house, i.e., the heating load at the outdoor design temperature, $\mathrm{T}_{\mathrm{OD}}$,

$\mathrm{C}=$ a correction factor, defined in the NBS testing and rating procedure for heat pumps to be 0.77 , and 
$\mathrm{HLH}=$ heating load hours.1

A map of HLH for the continental United States is shown in figure 3.2 The six major heating climate regions, including the corresponding $\mathrm{T}_{O D}$ and the midpoint HLH, as specified in the NBS testing and rating procedure for heat pumps in the heating mode, are shown in table 1 .

Based on the general method for calculating heat pump energy utilization in the cooling mode, ACR can be calculated using:

$$
\mathrm{ACR}=(\text { Cap95 })(\text { CLH })
$$

where:

Cap95 = the output capacity of a heat pump in the air conditioning mode when the outdoor temperature is $95^{\circ} \mathrm{F}$ and the indoor temperature is $80^{\circ} \mathrm{F}, 3$ and

CLH = cooling load hours, which are based on the number of annual compressor hours, a zero cooling load at $65^{\circ} \mathrm{F}$ outdoor temperature, and an indoor temperature in the range of $75^{\circ}-80^{\circ} \mathrm{F}$.

A map of CLH by region for the continental United States is provided in figure 4.4 Based on this map, six major cooling climatic regions are proposed here, as shown in table 8 . Table 8 also includes the annual cooling requirements calculated for each of these regions, as defined in the NBS method for estimating annual energy usage of heat pumps in the cooling mode. These ACR are based on the midpoint CLH for each cooling region. (2600 CLH are used for region F).

Given six heating regions and six cooling regions, 36 potential combined climate regions can result. However, only about 16 of these combined regions actually exist in the continental United States. Moreover, based on a comprehensive 1977 heat pump sales report by ARI, 1 which identified heat pump sales in 615 trading areas, 98.5 percent of all heat pump sales occurred in only ten

1

$\mathrm{HLH}=\frac{(24)\left(\text { Heating Degree Days, base } 65^{\circ} \mathrm{F}\right)}{\left(65^{\circ} \mathrm{F}-\mathrm{T}_{\mathrm{OD}}\right)}$

2 This map is taken directly from W. Parken, G. Kelly, and D. Didion, Method of Testing, Rating and Estimating the Heating Seasonal Performance of Heat Pumps.

3 Wet bulb temperatures are $75^{\circ} \mathrm{F}$ outdoors and $65^{\circ} \mathrm{F}$ indoors.

4 The CLH map was prepared under contract to NBS by York Division, Borg-Warner Corporation, and was based on results calculated in R.R. McConnell, J.R. Tobias, and L.W. Nelson, "Reducing Energy Consumption During the Cooling Season," ASHRAE Journal, June 1976, pp. 61-65. It is included in G. Kelly and W. Parken, Method of Testing, Rating and Estimating the Seasonal Performance of Central Air-Conditioners. 


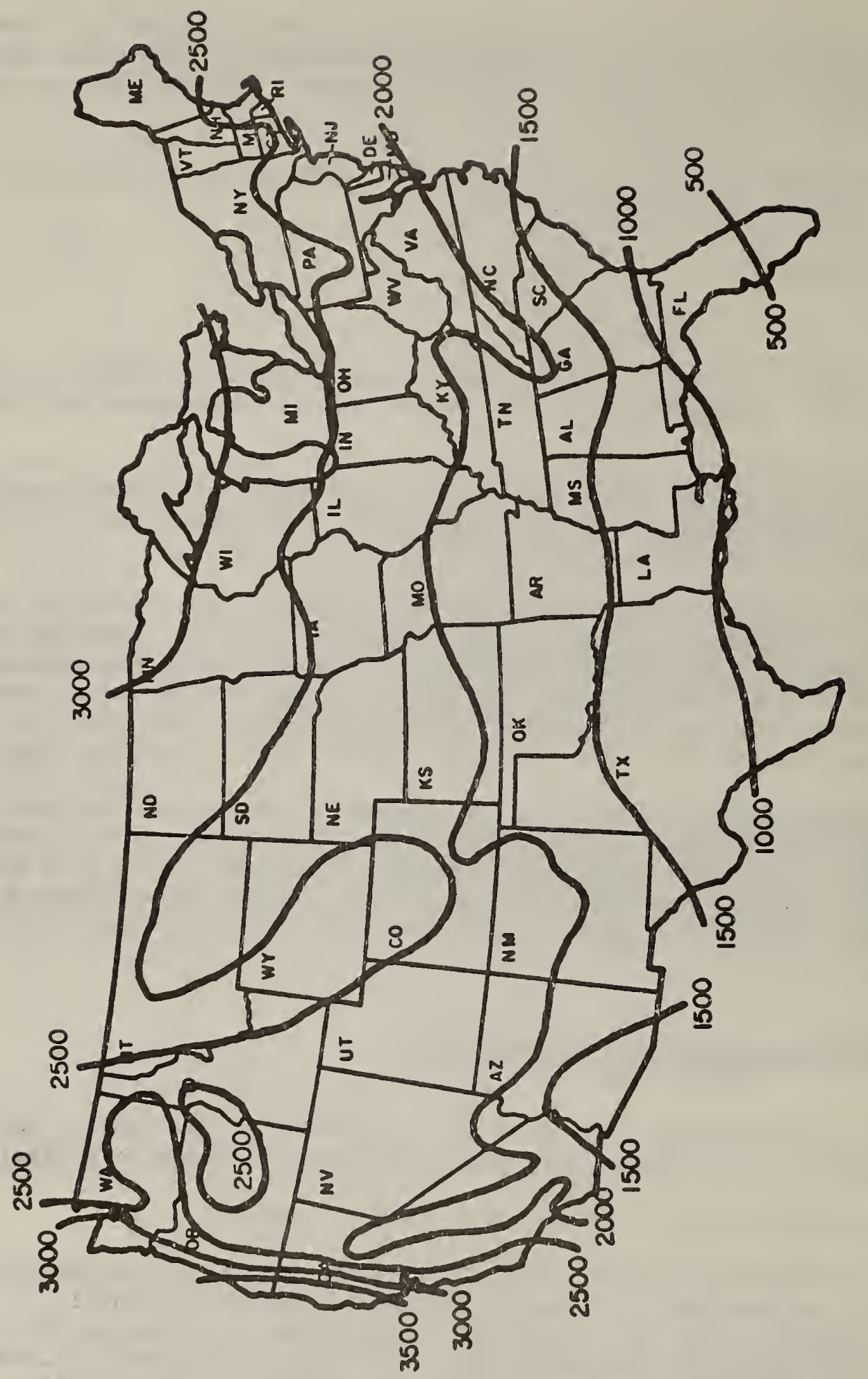

0 


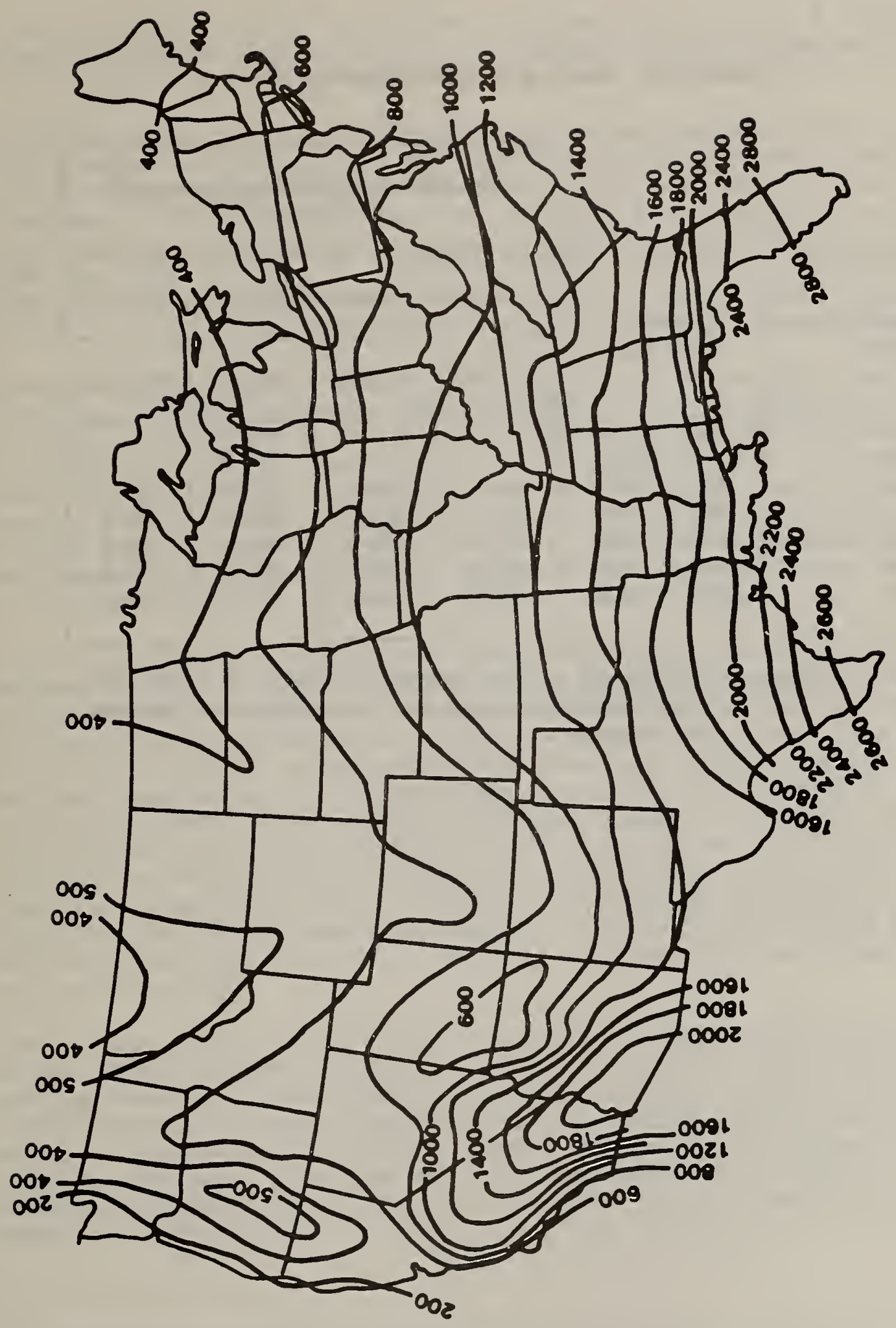

D 
Table 8. Cooling Climate Regions

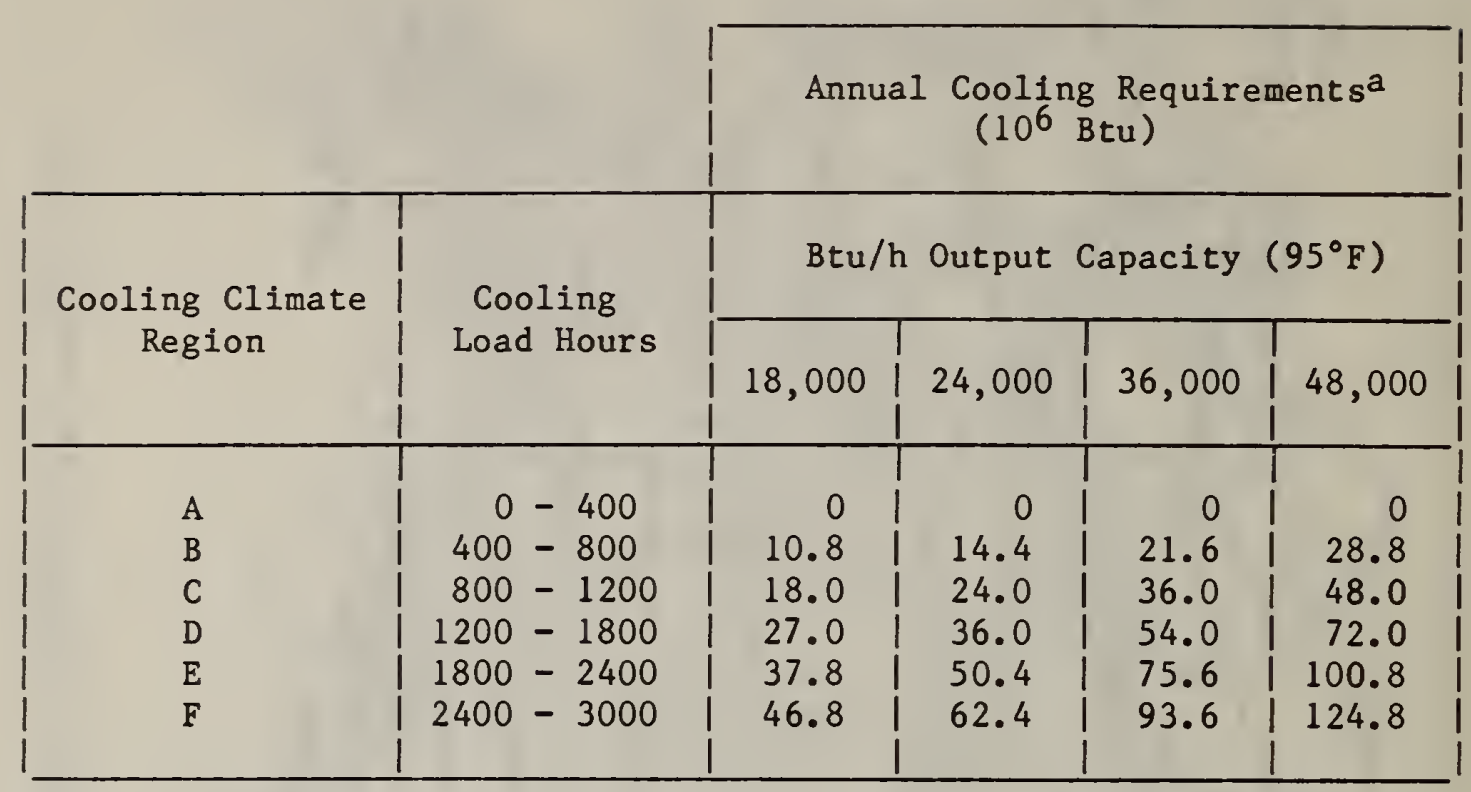

a $\mathrm{ACR}=\mathrm{CLH} \times \mathrm{Cap}_{95}$ :

Midpoints of CLH intervals are used (2600 CLH are used for region F); no cooling is assumed in region $A$. 
of these regions. These ten regions are identified in table 9, which also shows the midpoint HLH and CLH in each combined climate region and the percent of 1977 heat pump sales in those regions, based on the ARI data.

Annual $\mathrm{kWh}$ usage in each of these ten regions was then calculated for a 24,000 $\mathrm{Btu} / \mathrm{h}$ (Cap95) heat pump, based on the AHR and ACR data shown in tables 2 and 8 , respectively, and the SEER and corresponding HSPF data shown in table 2 . These annual $\mathrm{kWh}$ usages are shown in table 10 . The reduction in annual $\mathrm{kWh}$ usage due to each $0.5 \mathrm{Btu} /$ Wh increase in SEER (and corresponding increase in HSPF) are shown in table 11. Ultimately it is these savings (evaluated in terms of present-dollar values over the life of the heat pump) which must justify any cost increase related to the increased heat pump efficiency.

Examination of table 11 provides some preliminary information regarding the effects of climate regions on the $\mathrm{kWh}$ savings due to increases in efficiency. The annual $\mathrm{kWh}$ savings in the five combined regions having the lowest savings, II-D, III-C, IV-B, V-B, and VI-B are all quite similar for an increase in SEER from 8.0 to $8.5 \mathrm{Btu} / \mathrm{Wh}$, ranging from 352 to $382 \mathrm{kWh}$ per year. These five zones represent approximately 45 percent of all heat pump sales in 1977 . The largest savings occur in regions II-E and I-F, the regions with the greatest cooling requirements and smallest heating requirements. Note that these largest savings are only about 50 percent greater than the lowest savings.

Tables 12,13 , and 14 provide the annual $\mathrm{kWh}$ savings, based on the same methodology, for an $18,000,36,000$, and $48,000 \mathrm{Btu} / \mathrm{h}$ heat pumps. Note that the incremental savings for the larger units tend to be more than proportionally larger than the change in size alone would account for. This is because the increase in HSPF corresponding to a given size increase in SEER tends to be significantly greater for the larger units than for the smaller units. For both the 18,000 and $24,000 \mathrm{Btu} / \mathrm{h}$ heat pumps, regions II-D, III-C, IV-B, V-B, and VI-B have the smallest savings. For the 36,000 and $48,000 \mathrm{Btu} / \mathrm{h}$ units, $I-E$ replaces $V-B$ in the list of the five regions having the lowest savings. There is surprisingly little variation in the savings calculated for any given change in SEER within these five regions. For all but the $18,000 \mathrm{Btu} / \mathrm{h}$ unit, the savings vary by less than 10 percent; for the $18,000 \mathrm{Btu} / \mathrm{h}$ unit savings vary by 25 percent.

Again these results for HSPF, energy utilization, and energy savings are based on the general methods outlined in the NBS testing and rating procedures. They are not based on a given house with known heating and cooling requirements. Moreover they give results which appear to be significantly higher than what might be expected for newer housing built to more stringent insulation specifications than most older housing. For this reason it is useful to reevaluate these same factors, based on the use of a heat pump in a better defined operational context.

1 This regional analysis was based on unpublished data provided by the AirConditioning and Refrigeration Institute for the sales of 33 companies in 615 trading areas during 1977 . 
Table 9. Combined Climate Regions

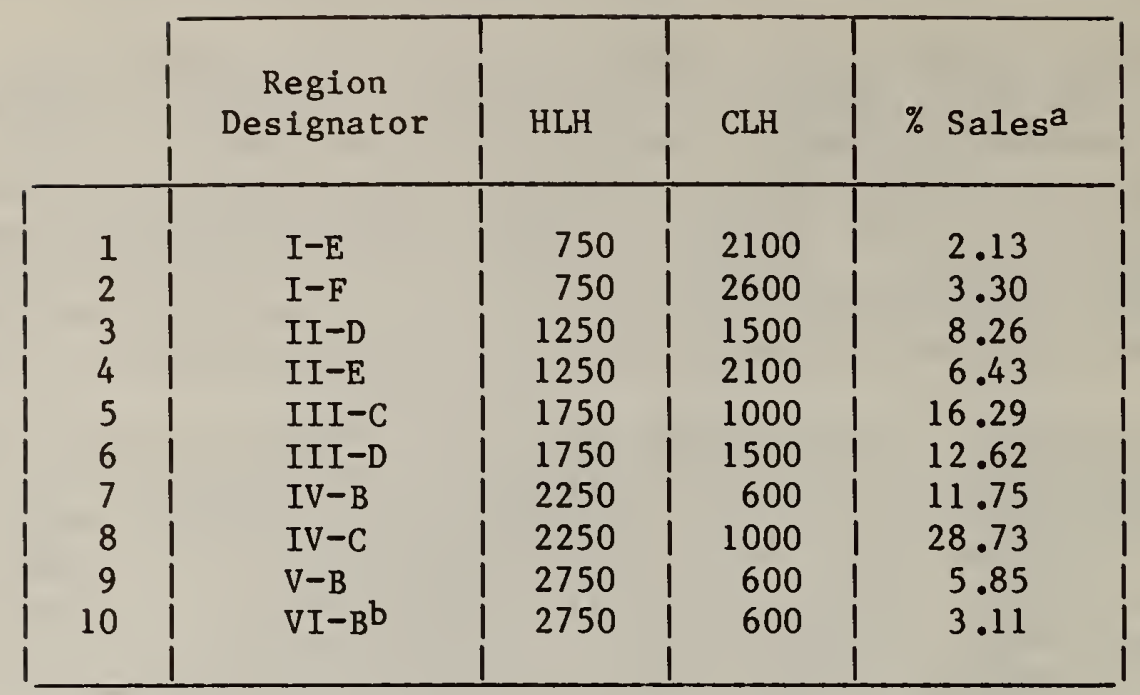

a Based on ARI report of 1977 sales. ( $1.53 \%$ of sales are outside these 10 regions.)

b Pacific coast region. 
Table 10. Annual kWh Usage for a $24,000 \mathrm{Btu} / \mathrm{h}$ Heat Pump by Combined Climate Region (General Method)

\begin{tabular}{|c|c|c|c|c|c|}
\hline & \multicolumn{5}{|c|}{ Combined Climate Region } \\
\hline & $I-E$ & $\mathrm{I}-\mathrm{F}$ & II-D & II-E & III-C \\
\hline $\begin{array}{l}7.0 \\
7.5 \\
8.0 \\
8.5\end{array}$ & $\begin{array}{l}8732 \\
8172 \\
7686 \\
7262\end{array}$ & $\begin{array}{r}10446 \\
9772 \\
9186 \\
8674\end{array}$ & $\begin{array}{l}8767 \\
8248 \\
7804 \\
7422\end{array}$ & $\begin{array}{r}10824 \\
10168 \\
9604 \\
9116\end{array}$ & $\begin{array}{r}10160 \\
9639 \\
9200 \\
8830\end{array}$ \\
\hline $\begin{array}{r}9.0 \\
9.5 \\
10.0 \\
10.5 \\
11.0\end{array}$ & $\begin{array}{l}6888 \\
6557 \\
6263 \\
5999 \\
5762\end{array}$ & $\begin{array}{l}8222 \\
7821 \\
7463 \\
7142 \\
6853\end{array}$ & $\begin{array}{l}7090 \\
6801 \\
6548 \\
6325 \\
6128\end{array}$ & $\begin{array}{l}8690 \\
8317 \\
7988 \\
7696 \\
7437\end{array}$ & $\begin{array}{l}8515 \\
8246 \\
8015 \\
7817 \\
7647\end{array}$ \\
\hline & III-D & $I V-B$ & $I V-C$ & $V-B$ & $V I-B$ \\
\hline $\begin{array}{l}7.0 \\
7.5 \\
8.0 \\
8.5\end{array}$ & $\begin{array}{l}11875 \\
11239 \\
10700 \\
10242\end{array}$ & $\begin{array}{l}13957 \\
13435 \\
13007 \\
12654\end{array}$ & $\begin{array}{l}15329 \\
14715 \\
14207 \\
13783\end{array}$ & $\begin{array}{l}19274 \\
18727 \\
18283 \\
17921\end{array}$ & $\begin{array}{l}9241 \\
8736 \\
8315 \\
7963\end{array}$ \\
\hline $\begin{array}{r}9.0 \\
9.5 \\
10.0 \\
10.5 \\
11.0\end{array}$ & $\begin{array}{l}9848 \\
9509 \\
9215 \\
8960 \\
8738\end{array}$ & $\begin{array}{l}12360 \\
12116 \\
11912 \\
11742 \\
11599\end{array}$ & $\begin{array}{l}13427 \\
13127 \\
12872 \\
12656 \\
12472\end{array}$ & $\begin{array}{l}17631 \\
17398 \\
17205 \\
17045 \\
16913\end{array}$ & $\begin{array}{l}7667 \\
7417 \\
7206 \\
7029 \\
6880\end{array}$ \\
\hline
\end{tabular}

a Annual $\mathrm{kWh}$ usage for a heat pump with an SEER greater than $8.5 \mathrm{Btu} / \mathrm{Wh}$ is based on extrapolation of the technical relationship between SEER and HSPF. 
Table 11. Reduction in Annual $\mathrm{kWh}$ Usage Due to Increased Efficiency: $24,000 \mathrm{Btu} / \mathrm{h}$ Heat Pump (General Method)

\begin{tabular}{|c|c|c|c|c|c|}
\hline \multirow{2}{*}{$\begin{array}{c}\text { Change in SEER } \\
(\mathrm{Btu} / \mathrm{Wh})\end{array}$} & \multicolumn{5}{|c|}{ Combined Climate Region } \\
\hline & $I-E$ & $I-F$ & II-D & $I I-E$ & III-C \\
\hline $\begin{array}{l}7.0-7.5 \\
7.5-8.0 \\
8.0-8.5\end{array}$ & $\begin{array}{l}560 \\
486 \\
424\end{array}$ & $\begin{array}{l}674 \\
586 \\
513\end{array}$ & $\begin{array}{l}519 \\
444 \\
382\end{array}$ & $\begin{array}{l}656 \\
564 \\
488\end{array}$ & $\begin{array}{l}522 \\
438 \\
370\end{array}$ \\
\hline $\begin{array}{r}8.5-9.0 \\
9.0-9.5 \\
9.5-10.0 \\
10.0-10.5 \\
10.5-11.0\end{array}$ & $\begin{array}{l}374 \\
331 \\
295 \\
264 \\
237\end{array}$ & $\begin{array}{l}452 \\
401 \\
358 \\
321 \\
289\end{array}$ & $\begin{array}{l}332 \\
289 \\
253 \\
223 \\
197\end{array}$ & $\begin{array}{l}426 \\
373 \\
329 \\
292 \\
259\end{array}$ & $\begin{array}{l}315 \\
269 \\
231 \\
198 \\
170\end{array}$ \\
\hline & III-D & $I V-B$ & $\mathrm{IV}-\mathrm{C}$ & $V-B$ & $V I-B$ \\
\hline $\begin{array}{l}7.0-7.5 \\
7.5-8.0 \\
8.0-8.5\end{array}$ & $\begin{array}{l}636 \\
538 \\
459\end{array}$ & $\begin{array}{l}522 \\
428 \\
353\end{array}$ & $\begin{array}{l}614 \\
508 \\
424\end{array}$ & $\begin{array}{l}547 \\
444 \\
362\end{array}$ & $\begin{array}{l}505 \\
421 \\
352\end{array}$ \\
\hline $\begin{array}{r}8.5-9.0 \\
9.0-9.5 \\
9.5-10.0 \\
10.0-10.5 \\
10.5-11.0\end{array}$ & $\begin{array}{l}393 \\
339 \\
294 \\
255 \\
222\end{array}$ & $\begin{array}{l}293 \\
244 \\
204 \\
171 \\
143\end{array}$ & $\begin{array}{l}356 \\
300 \\
255 \\
216 \\
184\end{array}$ & $\begin{array}{l}290 \\
233 \\
193 \\
160 \\
133\end{array}$ & $\begin{array}{l}296 \\
250 \\
211 \\
177 \\
149\end{array}$ \\
\hline
\end{tabular}

a Annual $\mathrm{kWh}$ usage for a heat pump with an SEER greater than $8.5 \mathrm{Btu} / \mathrm{Wh}$ is based on extrapolation of the technical relationship between SEER and HSPF. 
Table 12. Reduction in Annual $\mathrm{kWh}$ Usage Due to Increased Efficiency: 18,000 Btu/h Heat Pump (Genera1 Method)

\begin{tabular}{|c|c|c|c|c|c|}
\hline \multirow{2}{*}{$\begin{array}{l}\text { Change in SEER } \\
(\mathrm{Btu} / \mathrm{Wh})\end{array}$} & \multicolumn{5}{|c|}{ Combined Climate Region } \\
\hline & $I-E$ & $I-F$ & II-D & II-E & III-C \\
\hline $\begin{array}{l}7.0-7.5 \\
7.5-8.0 \\
8.0-8.5\end{array}$ & $\begin{array}{l}414 \\
358 \\
312\end{array}$ & $\begin{array}{l}499 \\
433 \\
378\end{array}$ & $\begin{array}{l}374 \\
317 \\
272\end{array}$ & $\begin{array}{l}477 \\
407 \\
351\end{array}$ & $\begin{array}{l}362 \\
301 \\
251\end{array}$ \\
\hline $\begin{array}{r}8.5-9.0 \\
9.0-9.5 \\
9.5-10.0 \\
10.0-10.5 \\
10.5-11.0\end{array}$ & $\begin{array}{l}274 \\
242 \\
215 \\
191 \\
171\end{array}$ & $\begin{array}{l}332 \\
294 \\
262 \\
234 \\
210\end{array}$ & $\begin{array}{l}234 \\
202 \\
176 \\
153 \\
134\end{array}$ & $\begin{array}{l}304 \\
265 \\
232 \\
204 \\
180\end{array}$ & $\begin{array}{l}210 \\
177 \\
149 \\
125 \\
105\end{array}$ \\
\hline & III-D & $I V-B$ & IV $-\mathrm{C}$ & $V-B$ & $V I-B$ \\
\hline $\begin{array}{l}7.0-7.5 \\
7.5-8.0 \\
8.0-8.5\end{array}$ & $\begin{array}{l}448 \\
376 \\
317\end{array}$ & $\begin{array}{l}344 \\
277 \\
224\end{array}$ & $\begin{array}{l}413 \\
337 \\
277\end{array}$ & $\begin{array}{l}349 \\
277 \\
218\end{array}$ & $\begin{array}{l}348 \\
285 \\
234\end{array}$ \\
\hline $\begin{array}{r}8.5-9.0 \\
9.0-9.5 \\
9.5-10.0 \\
10.0-10.5 \\
10.5-11.0\end{array}$ & $\begin{array}{l}269 \\
229 \\
196 \\
168 \\
144\end{array}$ & $\begin{array}{r}182 \\
148 \\
120 \\
97 \\
78\end{array}$ & $\begin{array}{l}229 \\
190 \\
158 \\
132 \\
109\end{array}$ & $\begin{array}{r}169 \\
136 \\
110 \\
90 \\
74\end{array}$ & $\begin{array}{r}192 \\
157 \\
128 \\
103 \\
82\end{array}$ \\
\hline
\end{tabular}

a Annual $\mathrm{kWh}$ usage for a heat pump with an SEER greater than $8.5 \mathrm{Btu} / \mathrm{Wh}$ is based on extrapolation of the technical relationship between SEER and HSPF. 
Table 13. Reduction in Annual $\mathrm{kWh}$ Usage Due to Increased Efficiency: $36,000 \mathrm{Btu} / \mathrm{h}$ Heat Pump (General Method)

\begin{tabular}{|c|c|c|c|c|c|}
\hline \multirow{2}{*}{$\begin{array}{c}\text { Change in SEER } \\
(\mathrm{Btu} / \mathrm{Wh})\end{array}$} & \multicolumn{5}{|c|}{ Combined Climate Region } \\
\hline & $\mathrm{I}-\mathrm{E}$ & $I-F$ & $I I-D$ & $I I-E$ & III-C \\
\hline $\begin{array}{l}7.0-7.5 \\
7.5-8.0 \\
8.0-8.5\end{array}$ & $\begin{array}{l}853 \\
741 \\
650\end{array}$ & $\begin{array}{r}1025 \\
891 \\
782\end{array}$ & $\begin{array}{l}811 \\
698 \\
605\end{array}$ & $\begin{array}{r}1017 \\
878 \\
764\end{array}$ & $\begin{array}{l}845 \\
717 \\
613\end{array}$ \\
\hline $\begin{array}{r}8.5-9.0 \\
9.0-9.5 \\
9.5-10.0 \\
10.0-10.5 \\
10.5-11.0\end{array}$ & $\begin{array}{l}573 \\
509 \\
455 \\
409 \\
359\end{array}$ & $\begin{array}{l}691 \\
615 \\
550 \\
494 \\
447\end{array}$ & $\begin{array}{l}528 \\
464 \\
410 \\
364 \\
325\end{array}$ & $\begin{array}{l}670 \\
591 \\
524 \\
467 \\
418\end{array}$ & $\begin{array}{l}528 \\
458 \\
399 \\
349 \\
306\end{array}$ \\
\hline & III-D & IV-B & IV-C & $V-B$ & VI-B \\
\hline $\begin{array}{l}7.0-7.5 \\
7.5-8.0 \\
8.0-8.5\end{array}$ & $\begin{array}{r}1016 \\
867 \\
746\end{array}$ & $\begin{array}{l}891 \\
743 \\
625\end{array}$ & $\begin{array}{r}1028 \\
863 \\
731\end{array}$ & $\begin{array}{l}969 \\
800 \\
665\end{array}$ & $\begin{array}{l}820 \\
693 \\
591\end{array}$ \\
\hline $\begin{array}{r}8.5-9.0 \\
9.0-9.5 \\
9.5-10.0 \\
10.0-10.5 \\
10.5-11.0\end{array}$ & $\begin{array}{l}646 \\
563 \\
493 \\
434 \\
384\end{array}$ & $\begin{array}{l}528 \\
450 \\
384 \\
330 \\
284\end{array}$ & $\begin{array}{l}623 \\
534 \\
460 \\
398 \\
346\end{array}$ & $\begin{array}{l}557 \\
469 \\
393 \\
322 \\
274\end{array}$ & $\begin{array}{l}506 \\
436 \\
377 \\
327 \\
284\end{array}$ \\
\hline
\end{tabular}

a Annual $\mathrm{kWh}$ usage for a heat pump with an SEER greater than $8.5 \mathrm{Btu} / \mathrm{Wh}$ is based on extrapolation of the technical relationship between SEER and HSPF. 
Table 14. Reduction in Annual $\mathrm{kWh}$ Usage Due to Increased Efficiency: 48,000 Btu/h Heat Pump (General Method)

\begin{tabular}{|c|c|c|c|c|c|}
\hline \multirow{2}{*}{$\begin{array}{c}\text { Change in SEER } \\
(\mathrm{Btu} / \mathrm{Wh})\end{array}$} & \multicolumn{2}{|c|}{ Combine } & \multicolumn{3}{|c|}{ Climate Region } \\
\hline & I-E & $\mathrm{I}-\mathrm{F}$ & II-D & II-E & III-C \\
\hline $\begin{array}{l}7.0-7.5 \\
7.5-8.0 \\
8.0-8.5\end{array}$ & $\begin{array}{r}1146 \\
997 \\
875\end{array}$ & $\begin{array}{l}1375 \\
1197 \\
1051\end{array}$ & $\begin{array}{r}1104 \\
952 \\
828\end{array}$ & $\begin{array}{l}1378 \\
1192 \\
1040\end{array}$ & $\begin{array}{r}1169 \\
998 \\
859\end{array}$ \\
\hline $\begin{array}{r}8.5-9.0 \\
9.0-9.5 \\
9.5-10.0 \\
10.0-10.5 \\
10.5-11.0\end{array}$ & $\begin{array}{l}773 \\
688 \\
615 \\
554 \\
500\end{array}$ & $\begin{array}{l}930 \\
828 \\
742 \\
668 \\
604\end{array}$ & $\begin{array}{l}726 \\
640 \\
568 \\
506 \\
453\end{array}$ & $\begin{array}{l}914 \\
809 \\
719 \\
643 \\
578\end{array}$ & $\begin{array}{l}744 \\
649 \\
569 \\
502 \\
444\end{array}$ \\
\hline & III-D & IV-B & IV-C & $V-B$ & $V I-B$ \\
\hline $\begin{array}{l}7.0-7.5 \\
7.5-8.0 \\
8.0-8.5\end{array}$ & $\begin{array}{l}1398 \\
1198 \\
1035\end{array}$ & $\begin{array}{r}1267 \\
1066 \\
904\end{array}$ & $\begin{array}{l}1450 \\
1226 \\
1046\end{array}$ & $\begin{array}{r}1406 \\
1173 \\
987\end{array}$ & $\begin{array}{r}1136 \\
966 \\
829\end{array}$ \\
\hline $\begin{array}{r}8.5-9.0 \\
9.0-9.5 \\
9.5-10.0 \\
10.0-10.5 \\
10.5-11.0\end{array}$ & $\begin{array}{l}901 \\
790 \\
696 \\
616 \\
548\end{array}$ & $\begin{array}{l}773 \\
664 \\
574 \\
498 \\
434\end{array}$ & $\begin{array}{l}898 \\
776 \\
675 \\
589 \\
517\end{array}$ & $\begin{array}{l}836 \\
713 \\
610 \\
525 \\
454\end{array}$ & $\begin{array}{l}716 \\
622 \\
544 \\
477 \\
419\end{array}$ \\
\hline
\end{tabular}

a Annual $\mathrm{kWh}$ usage for a heat pump with an SEER greater than $8.5 \mathrm{Btu} / \mathrm{Wh}$ is based on extrapolation of the technical relationship between SEER and HSPF. 


\subsection{ANNUAL HEATING AND COOLING REQUIREMENTS FROM THE BEPS PROGRAM}

A limited amount of data from the DoE Building Energy Performance Standards (BEPS) development program was obtained in order to provide a basis for estimating the AHR and ACR of new houses built to the relatively tight insulation standards expected. Table 15 shows the AHR, ACR, and the maximum hourly heating and cooling loads for the 1200 square foot "prototype" house insulated to the levels assumed in the BEPS development program in nine locations.1 Note that the ACR were calculated only during hours when the outdoor dry-bulb temperature is $78^{\circ} \mathrm{F}$ or greater. As a result, these ACR can be expected to be considerably less than those calculated in the general seasonal efficiency estimating methodology, in which cooling loads are assumed to exist whenever the outdoor temperature exceeds $65^{\circ} \mathrm{F}$.

Also shown in table 15 are the heating degree days base $55^{\circ} \mathrm{F}\left(\mathrm{HDD}_{55}\right)$ and cooling degree hours base $75^{\circ} \mathrm{F}\left(\mathrm{CDH}_{75}\right)$, which were computed from the same climate data ${ }^{2}$ used in the calculations of the AHR and ACR shown. These two climate variables are provided because they correlate well with the AHR and ACR shown, and thus can be used to interpolate AHR and ACR to other locations.

Maximum hourly heating and cooling loads are shown rather than design heating and cooling loads (DHL, DCL) since the latter were not available. These maximum loads indicate that an appropriately sized heat pump (i.e., one sized to provide about 10 percent more cooling at $95^{\circ} \mathrm{F}$ than the design cooling load) would be approximately $12,000 \mathrm{Btu} / \mathrm{h}$ except in Fresno and Phoenix, where it would be considerably higher. It is recognized that such a low capacity heat pump is not commercially available at this time. However, in order to provide a basis for comparison of the general method for estimating AHR and ACR with the AHR and ACR based on the available BEPS research data, a $12,000 \mathrm{Btu} / \mathrm{h}$ heat pump size will be assumed. It was necessary to adjust the BEPS data to correspond to the heating and cooling climate regions used in the general method. This was accomplished by plotting $\mathrm{HDD}_{55}$ and $\mathrm{CDH}_{75}$ data on the maps shown in figures 3 and 4 , respectively, and determining the $\mathrm{HDD}_{55}$ and $\mathrm{CDH}_{75}$ that best represent an approximate midpoint in each of the heating and cooling climate regions. AHR and ACR were then interpolated from the data in table 15

1 These data were calculated at Lawrence Berkeley Laboratories using the DOE-2 computer program, and served as the basis for the development of the proposed energy budgets for single-family detached residences published in the DoE Notice of Proposed Rulemaking on BEPS for new buildings, Nov. 28, 1979 . Insufficient data was made available for larger houses. Further information regarding the prototype house and energy analysis can be found in the BEPS "Technical Support Documents" available from the Department of Energy.

2 Test Reference Year climate data, which consist of measured hourly weather data for an entire year and are considered to be reasonably representative of the long-run climate for a given location, were used in the calculation of the AHR and ACR. 
Table 15. Space Heating and Cooling Data from BEPSa

\begin{tabular}{|c|c|c|c|c|c|c|}
\hline Location & $\left(10^{6}{ }_{\mathrm{Btu} / \mathrm{yr}}^{\mathrm{AHR}}\right)$ & $\begin{array}{l}\operatorname{MAX} H_{i} \mathrm{~L} \\
(\mathrm{kBtu} / \mathrm{h})\end{array}$ & $\begin{array}{c}\mathrm{ACR} \\
\left(10^{6} \mathrm{Btu}\right)\end{array}$ & $\begin{array}{l}\operatorname{MAX} C \cdot L \\
(k B t u / h)\end{array}$ & $\mathrm{HDD}_{55}{ }^{\mathrm{b}}$ & $\mathrm{CDH}_{75} \mathrm{~b}$ \\
\hline Atlanta & 10.5 & 20.0 & 7.5 & 11.2 & 1370 & 8264 \\
\hline Burbank & 1.5 & 11.7 & $\mathrm{~N} / \mathrm{A}$ & 13.1 & 82 & 1050 \\
\hline Chicago & 27.4 & 29.5 & 4.3 & 12.5 & 3768 & 5124 \\
\hline Fort Worth & 7.0 & 18.9 & 17.2 & 13.0 & 1048 & 24761 \\
\hline Fresno & 6.9 & 13.3 & 13.4 & 14.6 & 1044 & 21268 \\
\hline Houston & 3.9 & 18.1 & 16.9 & 12.3 & 601 & 21379 \\
\hline Minneapolis & 43.0 & 44.6 & 6.0 & 13.3 & 5934 & 7654 \\
\hline Phoentx & 1.8 & 11.6 & 25.4 & 18.3 & 404 & 47746 \\
\hline Washington, D.C. & 14.1 & 24.4 & 9.3 & 12.3 & 2185 & 12025 \\
\hline
\end{tabular}

a Based on data received directly from Lawrence Berkeley Laboratories.

b Computed directly from the Test Reference Year (TRY) climate data used in establishing AHR and ACR. 
to correspond to those midpoints. These are shown in table 16. In addition, design heating loads (DHL) corresponding to these midpoint AHR were estimated, based on the maximum heating loads shown in table 15, adjusted to correspond to the regionally specified outdoor design temperature (from table 1). These DHL are needed in order to calculate the hourly heating loads so that the seasonal heat pump efficiency can be estimated.

Since the heating balance point (the average outdoor temperature below which space heating is required) of the BEPS house tends to be approximately $55^{\circ} \mathrm{F}$, rather than $65^{\circ} \mathrm{F}$ used in the general method, the seasonal heat pump performance calculation procedure was adjusted to make heating loads proportional to $55^{\circ} \mathrm{F}$ minus the outdoor temperature, and to eliminate the two temperature bins between $55^{\circ} \mathrm{F}$ and $65^{\circ} \mathrm{F}$. This results in a somewhat lower HSPF because these two bins contain the temperatures for which the COP of the heat pump is the highest. The calculated incremental annual kWh energy savings for each 0.5 $\mathrm{Btu} / \mathrm{Wh}$ increase in SEER (and corresponding increase in HSPF) are shown in table 17 for each combined climate region, based on the use of a $12,000 \mathrm{Btu} / \mathrm{h}$ heat pump.

In order to provide comparable results using the general method described in subsection 4.1, the AHR, DHL, and ACR based on the general method were also estimated for a $12,000 \mathrm{Btu} / \mathrm{h}$ heat pump. The results are shown in table 18 . Note that the AHR which were calculated for the same heating climate regions using the general method tend to be significantly higher in the milder climates but reasonably similar in the colder climates. The ACR tend to be about 50-70 percent higher in all regions. Conversely, the DHL for both methods tend to be quite similar for the milder climates but somewhat low for the two coldest climates using the general method. (This confirms that the use of the midpoint DHL described in subsection 4.1 is a reasonable assumption except in the coldest regions. However, use of a higher DHL would result in an even higher estimate of annual energy usage and energy savings in those regions.)

Annual $\mathrm{kWh}$ savings corresponding to the AHR, DHL, and ACR based on the general method are shown in table 19. The order of increasing savings by combined climate region estimated for both the BEPS data and the general method is quite similar. However, the general method results in savings which tend to be about 50-100 percent greater than those estimated using the BEPS data. (In region IV-B, along the Pacific Coast, the savings from the general method tend to be more than twice those based on the BEPS data.)

While additional BEPS data for larger houses are not available, simple linear scaling of the AHR, $A C R$, and DHL was used to estimate annual $\mathrm{kWh}$ savings for the larger heat pump sizes $(18,000,24,000,36,000$, and 48,000 Btu/h). (The BEPS energy budgets implicitly assume proportionality of heating and cooling requirements with house size. In fact, it is unlikely that cooling requirements will increase proportionately with heating requirements unless internal and solar loads increase with house size). Comparison of these results with the results based on the general method for the larger heat pump sizes shows that the relative ordering of savings by climate region is quite similar in all cases. In addition, the relative size of the savings for the two methods is nearly identical to those reported for the $12,000 \mathrm{Btu} / \mathrm{h}$ heat pump size. 
Table 16. Estimated Space Heating and Cooling Requirements for BEPS House ${ }^{a}$

\begin{tabular}{|c|c|c|c|c|c|c|}
\hline Heating Region & I & II & III & IV & V & VI \\
\hline $\begin{array}{l}\text { AHR }\left(10^{6} \mathrm{Btu}\right) \\
\text { DHL }(k B t u / h)\end{array}$ & $\begin{array}{l}2.0 \\
8.5\end{array}$ & $\begin{array}{r}5.0 \\
12.5\end{array}$ & $\begin{array}{l}12.5 \\
17.5\end{array}$ & $\begin{array}{l}25.0 \\
24.0\end{array}$ & $\begin{array}{l}43.0 \\
33.0\end{array}$ & $\begin{array}{r}7.0 \\
11.5\end{array}$ \\
\hline Cooling Region & A & B & $\mathrm{C}$ & D & $\mathrm{E}$ & F \\
\hline $\operatorname{ACR}\left(10^{6} \mathrm{Btu}\right)$ & 0 & 4.2 & 8 & 11.6 & 15.0 & 20.0 \\
\hline
\end{tabular}

a $1200 \mathrm{sq}$. ft. one-story, single-family house. 
Table 17. Incremental kWh Savings: BEPS-Based; $12,000 \mathrm{Btu} / \mathrm{h}$ Heat Pump

\begin{tabular}{|c|c|c|c|c|c|}
\hline \multirow{2}{*}{$\begin{array}{c}\text { Change in SEER } \\
(\mathrm{Btu} / \mathrm{Wh})\end{array}$} & \multicolumn{5}{|c|}{ Combined Climate Region } \\
\hline & $I-E$ & $I-F$ & II-D & II-E & III-C \\
\hline $\begin{array}{l}7.0-7.5 \\
7.5-8.0 \\
8.0-8.5\end{array}$ & $\begin{array}{l}153 \\
132 \\
116\end{array}$ & $\begin{array}{l}201 \\
174 \\
152\end{array}$ & $\begin{array}{r}133 \\
113 \\
97\end{array}$ & $\begin{array}{l}165 \\
141 \\
122\end{array}$ & $\begin{array}{r}123 \\
100 \\
82\end{array}$ \\
\hline $\begin{array}{r}8.5-9.0 \\
9.0-9.5 \\
9.5-10.0 \\
10.0-10.5 \\
10.5-11.0\end{array}$ & $\begin{array}{r}101 \\
90 \\
80 \\
71 \\
64\end{array}$ & $\begin{array}{r}134 \\
119 \\
106 \\
95 \\
85\end{array}$ & $\begin{array}{l}83 \\
72 \\
63 \\
54 \\
48\end{array}$ & $\begin{array}{r}105 \\
92 \\
80 \\
71 \\
62\end{array}$ & $\begin{array}{l}67 \\
55 \\
45 \\
36 \\
29\end{array}$ \\
\hline & III-D & $I V-B$ & IV $-\mathrm{C}$ & $\mathrm{V}-\mathrm{B}$ & $V I-B$ \\
\hline $\begin{array}{l}7.0-7.5 \\
7.5-8.0 \\
8.0-8.5\end{array}$ & $\begin{array}{l}157 \\
130 \\
109\end{array}$ & $\begin{array}{l}97 \\
74 \\
57\end{array}$ & $\begin{array}{r}134 \\
106 \\
85\end{array}$ & $\begin{array}{l}95 \\
72 \\
56\end{array}$ & $\begin{array}{l}75 \\
61 \\
49\end{array}$ \\
\hline $\begin{array}{r}8.5-9.0 \\
9.0-9.5 \\
9.5-10.0 \\
10.0-10.5 \\
10.5-11.0\end{array}$ & $\begin{array}{l}91 \\
76 \\
64 \\
54 \\
45\end{array}$ & $\begin{array}{l}44 \\
34 \\
25 \\
18 \\
12\end{array}$ & $\begin{array}{l}69 \\
56 \\
45 \\
36 \\
28\end{array}$ & $\begin{array}{l}43 \\
33 \\
25 \\
18 \\
13\end{array}$ & $\begin{array}{l}39 \\
31 \\
24 \\
19 \\
14\end{array}$ \\
\hline
\end{tabular}

a Annual $\mathrm{kWh}$ usage for a heat pump with an SEER greater than $8.5 \mathrm{Btu} / \mathrm{Wh}$ is based on extrapolation of the technical relationship between SEER and HSPF. 
Table 18. Estimated Space Heating and Cooling Requirements Corresponding to a $12,000 \mathrm{Btu} / \mathrm{h}$ Heat Pumpa

\begin{tabular}{|l|c|c|c|c|c|c|c|}
\hline Heating Region & I & II & III & IV & V & VI \\
\hline AHR $\left(10^{6} \mathrm{Btu}\right)$ & 4.9 & 11.0 & 19.5 & 31.4 & 40.9 & 22.4 \\
\hline DHL (kBtu/h) & 8.4 & 11.4 & 14.5 & 18.2 & 19.4 & 10.5 \\
\hline & & & & & & & \\
\hline Cooling Region & A & B & C & D & E & F \\
\hline ACR $\left(10^{6}\right.$ Btu $)$ & 0 & 7.2 & 12.0 & 18.0 & 25.2 & 31.2 \\
\hline
\end{tabular}

a Based on general method described in section 4.1 . 
Table 19. Incremental kWh Savings: General Method; 12,000 Btu/h Heat Pump

\begin{tabular}{|c|c|c|c|c|c|}
\hline \multirow{2}{*}{$\begin{array}{c}\text { Change in SEER } \\
(\mathrm{Btu} / \mathrm{Wh})\end{array}$} & \multicolumn{5}{|c|}{ Combined Climate Region } \\
\hline & $I-E$ & $I-F$ & $I I-D$ & II-E & III-C \\
\hline $\begin{array}{l}7.0-7.5 \\
7.5-8.0 \\
8.0-8.5\end{array}$ & $\begin{array}{l}267 \\
230 \\
199\end{array}$ & $\begin{array}{l}324 \\
280 \\
243\end{array}$ & $\begin{array}{l}229 \\
192 \\
162\end{array}$ & $\begin{array}{l}298 \\
252 \\
215\end{array}$ & $\begin{array}{l}206 \\
167 \\
135\end{array}$ \\
\hline $\begin{array}{r}8.5-9.0 \\
9.0-9.5 \\
9.5-10.0 \\
10.0-10.5 \\
10.5-11.0\end{array}$ & $\begin{array}{l}174 \\
153 \\
134 \\
119 \\
106\end{array}$ & $\begin{array}{l}213 \\
188 \\
166 \\
148 \\
132\end{array}$ & $\begin{array}{r}137 \\
116 \\
99 \\
84 \\
71\end{array}$ & $\begin{array}{l}184 \\
158 \\
136 \\
118 \\
102\end{array}$ & $\begin{array}{r}109 \\
87 \\
69 \\
54 \\
41\end{array}$ \\
\hline & III-D & IV-B & IV $-\mathrm{C}$ & $V-B$ & $V I-B$ \\
\hline $\begin{array}{l}7.0-7.5 \\
7.5-8.0 \\
8.0-8.5\end{array}$ & $\begin{array}{l}263 \\
217 \\
179\end{array}$ & $\begin{array}{l}177 \\
137 \\
106\end{array}$ & $\begin{array}{l}223 \\
177 \\
142\end{array}$ & $\begin{array}{l}173 \\
133 \\
103\end{array}$ & $\begin{array}{l}191 \\
150 \\
116\end{array}$ \\
\hline $\begin{array}{r}8.5-9.0 \\
9.0-9.5 \\
9.5-10.0 \\
10.0-10.5 \\
10.5-11.0\end{array}$ & $\begin{array}{r}148 \\
122 \\
101 \\
82 \\
67\end{array}$ & $\begin{array}{l}81 \\
61 \\
45 \\
31 \\
18\end{array}$ & $\begin{array}{r}113 \\
89 \\
70 \\
53 \\
39\end{array}$ & $\begin{array}{l}76 \\
58 \\
43 \\
31 \\
21\end{array}$ & $\begin{array}{l}88 \\
65 \\
46 \\
30 \\
16\end{array}$ \\
\hline
\end{tabular}

a Annual $\mathrm{kWh}$ usage for a heat pump with an SEER greater than $8.5 \mathrm{Btu} / \mathrm{Wh}$ is based on extrapolation of the technical relationship between SEER and HSPF. 
The results of the BEPS data analysis imply that the general method for estimating annual $\mathrm{kWh}$ savings may be useful for estimating order-of-magnitude savings in a consistent manner, but that these savings tend to be, on the average, about 75 percent larger than those based on the BEPS data. Since the BEPS heating and cooling load data are based on more tightly insulated new houses than the existing stock of housing and a more conservative operating profile, it is not surprising that the general method estimates higher $\mathrm{kWh}$ savings than those based on the BEPS data reported above. 


\section{DETERMINATION OF MAXIMUM COST-EFFECTIVE EFFICIENCY LEVELS}

Determination of the economically optimal HSPF and SEER for a heat pump system in a given installation requires that each of these efficiency measures be increased up to the point where incremental life-cycle dollar savings equals incremental costs, as shown in section 2, figure 1 . There are a number of important variables which determine economic optimality, including annual heating and cooling requirements, kWh prices, time horizons, and discount rates. Since many of these variables vary widely from place to place or person to person, it is not possible to identify a universal level of HSPF and SEER that can be considered to be optimal for the United States. However, the same optimality criterion can be used to determine maximum efficiency levels which can be economically justified from a more generalized (or "social") viewpoint in a prescribed percentile of installations. This requires that a social discount rate and an incremental (i.e., new capacity) kWh price be established either regionally or nationwide. The Department of Energy will likely establish such assumptions for analyses of other appliances and building energy standards. Ideally, these same assumptions will be used for all analyses pertaining to standards development. In addition, a useful system lifetime and all costs associated with improvements in heat pump efficiency must be quantified for the analysis.

In this section a generalized methodology will be demonstrated for establishing maximum HSPF and SEER levels for heat pumps that are economically justified in a given percentile of installations. Examples shown are based on the annual $\mathrm{kWh}$ savings determined in section 3 ; an incremental electricity price of $\$ 0.05 /$ $\mathrm{kWh}$, increasing in real terms at two percent per year; and a real discount rate of four percent. A 10-year life is assumed for the heat pump with no compressor replacement during that time period. However, further analysis using assumptions specified by DoE would be required to establish the reference basis for actual standards development.

In table 20, incremental present-value, life-cycle dollar savings are shown for a $36,000 \mathrm{Btu} / \mathrm{h}$ capacity $\left(95^{\circ} \mathrm{F}\right.$ outdoor temperature) heat pump. These savings are calculated for $0.5 \mathrm{Btu} / \mathrm{Wh}$ increases in SEER (and corresponding increases in HSPF) over a range of SEER's from 7.0 to $11.0 \mathrm{Btu} / \mathrm{Wh}$ for each of the 10 climate regions identified in section 4 . The savings are based on the reductions in annual kWh usage shown in table 13. However, these $\mathrm{kWh}$ savings have been adjusted to correspond more closely with the results derived from the BEPS data analysis by dividing each value by 1.75 , as suggested in section 4.2 . Thus, each data point shown in table 20 was calculated as:

$$
\text { IS }=\left(\frac{\Delta k W h}{1.75}\right)(P)\left(\mathrm{UPW}^{*}\right)
$$

where: IS = incremental present-value life-cycle savings, $\Delta \mathrm{kWh}=$ reduction in annual $\mathrm{kWh}$ usage (from table 13), $1.75=$ adjustment factor, 
Table 20. Incremental Life-Cycle Savings Due to Increased Efficiency: $36,000 \mathrm{Btu} / \mathrm{h}$ Heat Pump

\begin{tabular}{|c|c|c|c|c|c|}
\hline \multirow{2}{*}{$\begin{array}{c}\text { Change in SEER } \\
(\mathrm{Btu} / \mathrm{Wh})\end{array}$} & \multicolumn{5}{|c|}{ Combined Climate Region } \\
\hline & $I-E$ & $I-F$ & II-D & II-E & III-C \\
\hline $\begin{array}{r}7.0-7.5 \\
7.5-8.0 \\
8.0-8.5 \\
8.5-9.0 \\
9.0-9.5 \\
9.5-10.0 \\
10.0-10.5 \\
10.5-11.0\end{array}$ & $\begin{array}{r}\$ 219 \\
190 \\
167 \\
147 \\
131 \\
117 \\
105 \\
95\end{array}$ & $\begin{array}{r}\$ 264 \\
229 \\
201 \\
178 \\
158 \\
141 \\
127 \\
115\end{array}$ & $\begin{array}{r}\$ 209 \\
179 \\
156 \\
136 \\
119 \\
105 \\
94 \\
84\end{array}$ & $\begin{array}{r}\$ 262 \\
226 \\
196 \\
172 \\
152 \\
135 \\
120 \\
107\end{array}$ & $\begin{array}{r}\$ 217 \\
184 \\
158 \\
136 \\
118 \\
103 \\
90 \\
79\end{array}$ \\
\hline & III-D & IV-B & IV-C & $V-B$ & $V I-B$ \\
\hline $\begin{array}{r}7.0-7.5 \\
7.5-8.0 \\
8.0-8.5 \\
8.5-9.0 \\
9.0-9.5 \\
9.5-10.0 \\
10.0-10.5 \\
10.5-11.0\end{array}$ & $\begin{array}{r}\$ 261 \\
223 \\
192 \\
166 \\
145 \\
127 \\
112 \\
99\end{array}$ & $\begin{array}{r}\$ 229 \\
191 \\
161 \\
136 \\
116 \\
99 \\
85 \\
73\end{array}$ & $\begin{array}{r}\$ 264 \\
222 \\
188 \\
160 \\
137 \\
118 \\
102 \\
89\end{array}$ & $\begin{array}{r}\$ 249 \\
206 \\
171 \\
143 \\
121 \\
101 \\
83 \\
70\end{array}$ & $\begin{array}{r}\$ 211 \\
178 \\
152 \\
130 \\
112 \\
97 \\
84 \\
73\end{array}$ \\
\hline
\end{tabular}




\begin{abstract}
$P=$ price per $k W h$ in base year (assumed to be $\$ 0.05$ ), and UPW $W^{*}$ modified uniform present worth factor (assumed to be $9.00^{1}$ ).
\end{abstract}

These incremental savings are shown graphically in figure 5, plotted at the midpoint of each $0.5 \mathrm{Btu} / \mathrm{Wh}$ increase in SEER from 7.0 to $11.0 \mathrm{Btu} / \mathrm{Wh}$. Note that there is relatively little spread among the savings, considering the wide range of geographic locations included. Note also that there is some shifting in the relative ranking of climate regions (in terms of savings) as the SEER is increased over the range shown. In general, climate regions with the lowest annual cooling requirements and the highest annual heating requirements have the lowest savings as the heat pump efficiency is increased at the upper end of the SEER range examined. (This is because the empirical model used to relate HSPF to SEER produces relatively small changes in HSPF at the upper end of the SEER scale examined.)

Incremental heat pump cost data developed explicitly for higher efficiency equipment have not yet been refined to the point where they can be used for standards development purposes. In general, such data can be derived from two distinct sources: (1) a statistical analysis of retail cost data and corresponding published efficiency data; and (2) a cost engineering analysis of the design changes needed to improve heat pump efficiency.

Statistical analysis was attempted by the authors using retail cost data collected by Oak Ridge National Laboratory for 41 heat pumps. ${ }^{2}$ While a positive correlation between EER and cost is clearly established, the correlation is too weak to provide a meaningful basis for estimating incremental costs.

While no cost engineering data specific to residential size heat pumps is readily available, a technical report from the Carrier Corporation ${ }^{3}$ provides an engineering cost analysis of efficiency improvements to central air conditioners. Since the basic changes that were incorporated into the outdoor unit in. that study (increased heat exchanger size and improved compressor efficiency) are the same changes that would likely be made to improve seasonal heat pump efficiency, this cost data will be representative of heat pump improvements as we11. These Carrier data, adjusted to represent the estimated change in 1980 retail cost (from 1978 estimates) for a $36,000 \mathrm{Btu} / \mathrm{h}$ central air conditioner,

$1 U_{P W^{*}}=\left(\frac{1.02}{0.02}\right)\left(1-\left(\frac{1.02}{1.04}\right)^{10}\right)=9.00$.

See Appendix A for derivation of UPW* calculation.

2 J.K. Martin and D. L. O'Neal, "An Energy and Cost Analysis of Residential Heat Pumps in Northern Climates," Oak Ridge National Laboratory, Oak Ridge, Tenn., 1980.

3 Unpublished technical report entitled "Analysis to Determine Minimum Efficiency Levels," 1979, obtained through private communication. 


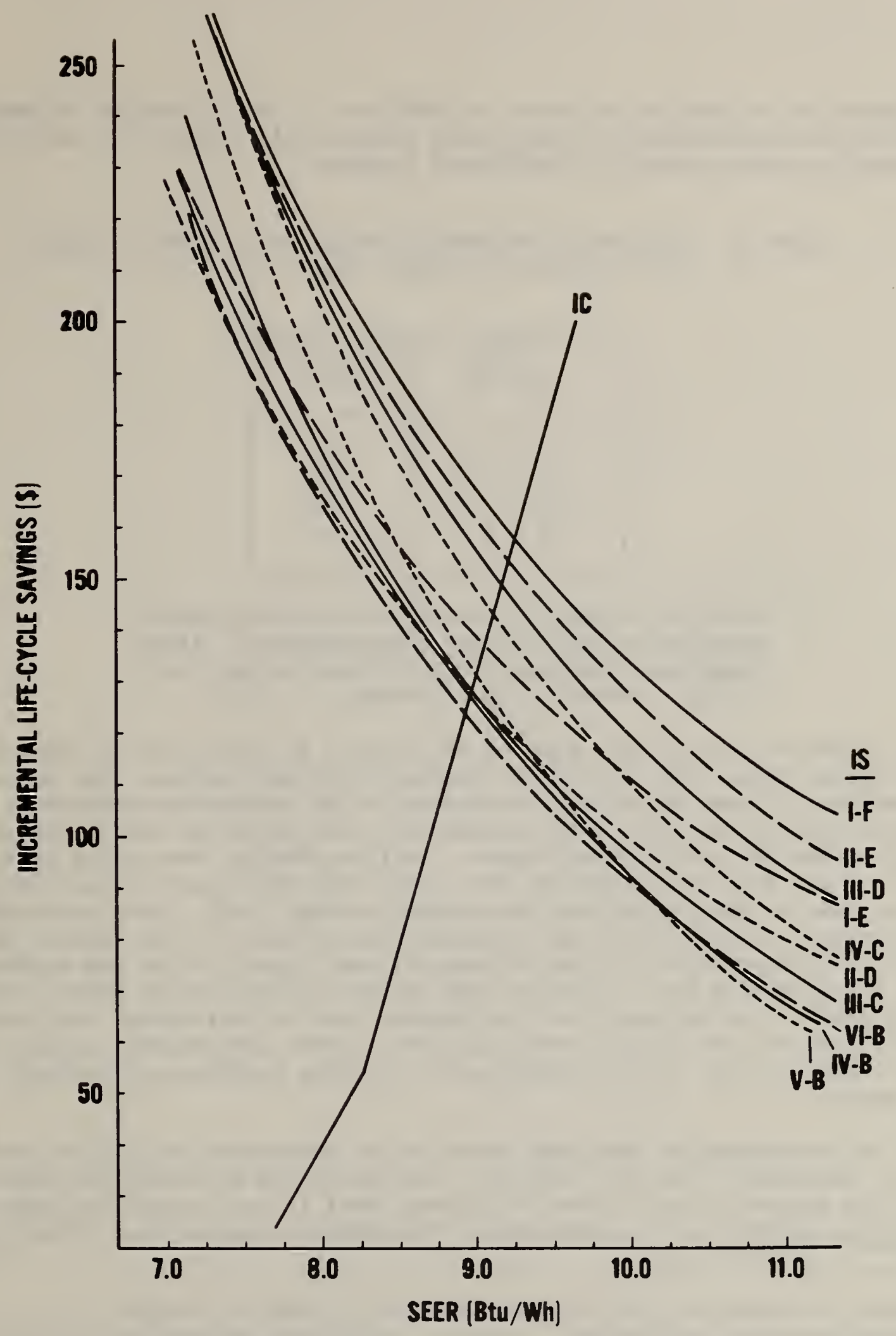

Figure 5. Illustration of Incremental Savings and Costs of 0.5 Btu/Wh Increase in SEER: 36,000 Btu/h Heat Pump 
are shown for $0.5 \mathrm{Btu} / \mathrm{Wh}$ increases in SEER from 7.5 to $9.5 \mathrm{Btu} / \mathrm{Wh}$ in Table 21 . These data are presented for purposes of example only and are not intended to be used for actual standards development purposes.

Table 21. Estimated Incremental Retail Costs (1980 dollars) for a $36,000 \mathrm{Btu} / \mathrm{h}$ Heat Pumpa

\begin{tabular}{|c|c|}
\hline $\begin{array}{c}\text { SEER } \\
(\mathrm{Btu} / \text { Wh })\end{array}$ & $\begin{array}{c}\text { Inc remental } \\
\text { Cost }\end{array}$ \\
\hline $7.5-8.0$ & $\$ 27$ \\
$8.0-8.5$ & 54 \\
$8.5-9.0$ & 105 \\
$9.0-9.5$ & 153 \\
\hline
\end{tabular}

a Based on a Carrier Corporation technical report obtained through private correspondence. 1978 costs were increased to 1980 costs using a GNP deflator change of 19.2 percent.

These incremental costs were plotted on figure 5 as curve "IC" in order to allow visual comparison between incremental costs and savings. The maximum cost-effective level of SEER corresponding to the assumptions made above is found at the intersection of the incremental cost curve and the incremental savings curve for each climate region. In this example, the points of intersection range from $8.9 \mathrm{Btu} /$ Wh for the region with the lowest savings (VI-B) to $9.25 \mathrm{Btu} / \mathrm{Wh}$ for the region with the highest savings (I-F). This remarkably narrow range is due to both the relatively narrow range of kWh savings by region and the steepness of the incremental cost curve. Since the technologically feasible SEER for a new heat punp system is likely to be higher than $10.0 \mathrm{Btu} / \mathrm{Wh}$, it is unlikely that the maximum level of efficiency that can be justified economically will reach this level. Thus the economic constraint would likely prevail in the development of ininimum performance standards for heat pumps.

Since the percentage of heat pump sales can be determined for each climate region (see table 9 for 1977 figures), the cumulative percentage of sales which fall into regions where a given efficiency level is cost effective under the conditions assumed can be calculated. For example, suppose that a heat pump

1 Indoor coil size was held constant in order to assure adequate dehumidification performance. However, increasing the size of the indoor coil can provide a less costly means of increasing HSPF and SEER than shown in table 21. In addition, improved defrosting procedures, and two-speed or variable speed compressors may also lead to lower incremental costs for higher heat pump performance. 


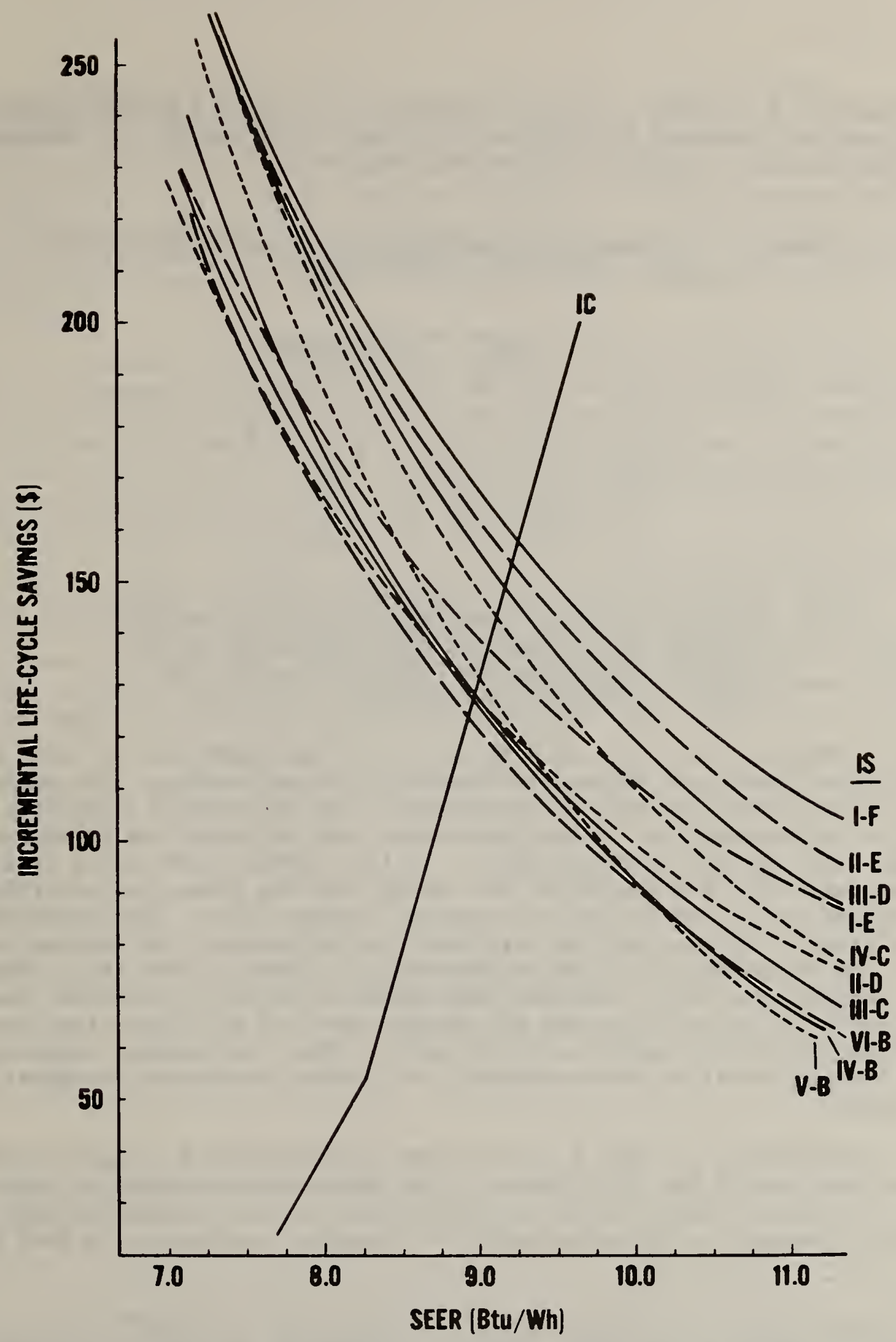

Figure 5. Illustration of Incremental Savings and Costs of 0.5 $\mathrm{Btu} /$ Wh Increase in SEER: 36,000 Btu/h Heat Pump 
are shown for $0.5 \mathrm{Btu} / \mathrm{Wh}$ increases in SEER from 7.5 to $9.5 \mathrm{Btu} / \mathrm{Wh}$ in Table 21 . These data are presented for purposes of example only and are not intended to be used for actual standards development purposes.

Table 21. Estimated Incremental Retail Costs (1980 dollars) for a $36,000 \mathrm{Btu} / \mathrm{h}$ Heat Pumpa

\begin{tabular}{|c|c|}
\hline $\begin{array}{c}\text { SEER } \\
(\text { Btu/Wh })\end{array}$ & $\begin{array}{c}\text { Incremental } \\
\text { Cost }\end{array}$ \\
\hline $7.5-8.0$ & $\$ 27$ \\
$8.0-8.5$ & 54 \\
$8.5-9.0$ & 105 \\
$9.0-9.5$ & 153 \\
\hline
\end{tabular}

a Based on a Carrier Corporation technical report obtained through private correspondence. 1978 costs were increased to 1980 costs using a GNP deflator change of 19.2 percent.

These incremental costs were plotted on figure 5 as curve "IC" in order to allow visual comparison between incremental costs and savings. The maximum cost-effective level of SEER corresponding to the assumptions made above is found at the intersection of the incremental cost curve and the incremental savings curve for each climate region. In this example, the points of intersection range from $8.9 \mathrm{Btu} / \mathrm{Wh}$ for the region with the lowest savings (VI-B) to $9.25 \mathrm{Btu} / \mathrm{Wh}$ for the region with the highest savings ( $I-F)$. This remarkably narrow range is due to both the relatively narrow range of kWh savings by region and the steepness of the incremental cost curve. Since the technologically feasible SEER for a new heat pump system is likely to be higher than $10.0 \mathrm{Btu} / \mathrm{Wh}$, it is unlikely that the maximum level of efficiency that can be justified economically will reach this level. Thus the economic constraint would likely prevail in the development of minimum performance standards for heat pumps.

Since the percentage of heat pump sales can be determined for each climate region (see table 9 for 1977 figures), the cumulative percentage of sales which fall into regions where a given efficiency level is cost effective under the conditions assumed can be calculated. For example, suppose that a heat purip

1 Indoor coil size was held constant in order to assure adequate dehumidification performance. However, increasing the size of the indoor coll can provide a less costly means of increasing HSPF and SEER than shown in table 21. In addition, improved defrosting procedures, and two-speed or variable speed compressors may also lead to lower incremental costs for higher heat pump performance. 
efficiency standard requires SEER to be no less than $9.1 \mathrm{Btu} / \mathrm{Wh}$ (with corresponding HSPF determined for a specified operating profile as outlined in section 3 ). 1 The standard would then be cost-justified under the conditions assumed in regions IV-C, III-D, II-E, and I-F, or a total of 51 percent of sales (based on 1977 sales data tabulated in table 9). As the minimum SEER and corresponding HSPF are reduced, the percentage of sales for which the standard will be cost-justified will increase. At an SEER of $8.9 \mathrm{Btu} / \mathrm{Wh}$ the minimum standard would be cost effective under the conditions assumed for 99 percent of all sales.

It must be stressed that the determination of cost effectiveness in each region is based on a number of assumptions which may not be valid for each individual installation. Conservative estimates of annual heating and cooling requirements will reduce the number of installations where savings are overestimated. However, the use of $\mathrm{kWh}$ prices attributable to new generating capacity and a social discount rate will result in present-value savings that may be greater than can be anticipated by many individual homeowners.

In addition, a number of other economic factors must be considered in minimum standards development that fall outside the scope of this report. These include the economic impact of the standard on manufacturers as well as consumers, lessening of product performance, the effect on industry competition, the impact on export and import shipments, and the magnitude of potential energy savings and their significance in meeting national energy conservation goals.

1 Using table 6, which provides the HSPF corresponding to specified SEER levels for a $36,000 \mathrm{Btu} / \mathrm{h}$ heat pump in each heating climate, the HSPF corresponding to an SEER of $8.75 \mathrm{Btu} / \mathrm{Wh}$ can be determined for any heating region. For example, if region III were specified in evaluating heat pump performance, the HSPF of 2.144 would correspond to an SEER of $8.75 \mathrm{Btu} / \mathrm{Wh}$. 


\subsection{SUMMARY}

The Department of Energy has been mandated by Congress to develop energy efficiency standards for new heat pumps which will result in the maximum improvement in energy efficiency that is both technologically feasible and economically justified. The purpose of this report is to provide a methodology for determining, in a life-cycle cost context, the maximum improvement that is economically justified. In general, economic justification is likely to constrain a minimum standard from achieving the level of efficiency that is technologically feasible.

In section 2, economic criteria for establishing an optimal efficiency level for an appliance were outlined. Since the optimal efficiency level will vary significantly as a function of a number of key factors, including climate, operating profile, projected energy prices, and discount rate, it is impossible to establish an economically optimal basis for minimum standards development. However, these same economic criteria can be used to determine minimum efficiency levels that can be cost-justified from a national (or societal) viewpoint in an estimated percentage of installations.

In section 3 the dual nature of heat pump efficiency is explored. Since the efficiency in the heating mode (HSPF) is measured differently than the efficiency in the cooling mode (SEER), separate efficiency ratings must be established. However, these efficiency ratings are technically interrelated and this interrelationship is quantified using a statistical analysis of currently available heat pump units. In section 4, incremental annual energy savings were calculated in ten different climate regions for $0.5 \mathrm{Btu} / \mathrm{Wh}$ increases in SEER and corresponding increases in HSPF.

In section 5, the benefit-cost methodology for establishing maximum levels of heat pump efficiency that can be cost justified is demonstrated. However, the results of that analysis are for purposes of example only; certain key assumptions regarding energy costs, discount rates, useful appliance life, and incremental heat pump costs would need to be defined by the Department of Energy to be consistent with the other appliance efficiency programs that they administer.

\subsection{CONCLUSIONS}

A number of conclusions can be drawn from this report that may have direct relevance to ininimuin standards development for heat pumps. (1) The technical interclationship between steady-state heat pump performance in the heating and cooling modes can be quantified to a degree that is quite satisfactory from a statistical standpoint. This statistical relationship is based on the entire list of commercially available residential air-to-air heat pumps certified by the Air-Conditioning and Refrigeration Institute, edited to remove identical units with different brand names. This statistical relationship included heat pumps having energy efficiency ratios (EER at $95^{\circ} \mathrm{F}$ ) ranging from a low of 6.0 to a high of $8.55 \mathrm{Btu} / \mathrm{Wh}$. However, the relationship estimated 
from this data base may not be accurate outside this range. Moreover, the fact that the highest efficiency heat pump listed has an EER of $8.55 \mathrm{Btu} / \mathrm{Wh}$ would imply that several years will likely be required before the industry could comply with a minimum EER requirement higher than that point. As more units are added to the list, especially units with an EER greater than $8.0 \mathrm{Btu} / \mathrm{Wh}$, the statistical relationship should be recalculated.

(2) A given improvement in EER generally results in a significantly smaller increase in heating efficiency, especially in the colder regions of the United States. As a result, the annual $\mathrm{kWh}$ savings from improved heat pump design in those colder climates tend to be smaller than the $\mathrm{kWh}$ savings realized in regions with substantial air conditioning requirements. Research in improving heat pump performance in the heating mode relative to the cooling mode may be useful in developing heat pumps for northern climates.

(3) In general, the annual $\mathrm{kWh}$ savings due to a given increase in heat pump efficiency tend to be reasonably similar in most regions of the United States. The two regions where $\mathrm{kWh}$ savings are lowest are the coastal areas of Washington State and extreme southern California. The highest savings are in Florida and along the Gulf Coast. In the examples of economically justified maximum efficiency levels calculated in this report, there is relatively little variation by climate region. The selection of projected energy prices, discount rate, useful life, and incremental heat pump costs will likely have considerably more impact on the final outcome of the analysis than regional considerations.

(4) The current testing and rating procedures used to determine annual heating and cooling requirements and design heating requirements for a typical heat pump installation will likely significantly overstate these parameters in new, better insulated and more conservatively operated houses. As a result, the $\mathrm{kWh}$ savings calculated using these general methods will likely be overstated as we11.

(5) The increase in heating efficiency due to a given increase in cooling efficiency tends to increase significantly as output capacity is increased. Thus the maximum level of heat pump efficiency that can be economically justified may be greater for larger capacity heat pumps than for the smaller sizes. This may encourage the use of larger heat pumps for use in northern climates than would be selected based on cooling requirements alone.

\subsection{RECOMMENDATIONS FOR FURTHER RESEARCH}

Several key areas of research become apparent in establishing a reference basis for minimum standards development. These largely revolve around the problem of calculating expected annual $\mathrm{kWh}$ savings that correspond to given increases in heating and cooling performance. More work is required to extend the statistical model of heating and cooling interdependence beyond an EER rating of 8.5 Btu/Wh. An improved methodology must also be developed for estimating annual heating and cooling requirements and design heating and cooling loads since these are critical determinants of kWh usage (and thus savings) and since they appear to be overestimated by the testing and rating procedures for tightly 
constructed, BEPS-type houses. Another area of significant concern is the development of a reliable data base of incremental heat pump costs for all sizes of heat pumps. This is a major determinant of maximum cost-justified improvements in heat pump efficiency for which little data are currently available. 
Carrier Corporation, unpublished technical report entitled "Analysis to Determine Minimum Efficiency Levels," 1979.

Directory of Certified Unitary Air-Conditioners, Air-Source Unitary Heat Pumps, Sound-Rated Outdoor Unitary Equipment, and Central System Humidifiers, January 1 - June 30, 1980, Air-Conditioning and Refrigeration Institute, Arlington, Va., 1980.

Kelly, G.E., and Parken, W.H., Method of Testing, Rating and Estimating the Seasonal Performance of Central Air-Conditioners and Heat Pumps Operating in the Cooling Mode, NBSIR 77-1271, National Bureau of Standards, Washington, D.C., April 1978.

Marsha11, Harold E. and Ruegg, Rosalie T., Simplified Energy Design Economics, NBS SP 544, National Bureau of Standards, Washington, D.C., January 1980.

Martin, J.K. and O'Neal, D.L., "An Energy and Cost Analysis of Residential Heat Pumps in Northern Climates," Oak Ridge National Laboratory, Oak Ridge, Tenn., 1980.

McConnell, R.R., Tobias, J.R. and Nelson, L.W., "Reducing Energy Consumption During the Cooling Season," ASHRAE Journal, June 1976.

Parken, Walter H., Kelly, George E., and Didion, David A., Method of Testing, Rating and Estimating the Heating Seasonal Performance of Heat Pumps, NBSIR 80-2002, National Bureau of Standards, Washington, D.C., April 1980 .

Pindyck, Robert S. and Rubinfeld, Daniel L., Econometric Models and Economic Forecasts, McGraw-Hill Book Company, New York, 1976.

Thomas, Steven B., Tree, David R., and Goldschmidt, Victor W., "A Study of the $P$ rediction and Measurement of Air Conditioning System Seasonal Performance Characteristics - Compilation of Data and Analysis of Test Procedure for SEER," Ray W. Herrick Laboratories, Purdue University, Lafayette, Ind., sponsored by the Air-Conditioning and Refrigeration Institute, 1979.

U.S. Department of Energy, "Advance Notice of Proposed Rulemaking and Notice of Public Meetings Regarding Energy Efficiency Standards for Nine Types of Consumer Products," Federal Register, Vol. 44, No. 1, January 2, 1979.

U.S. Department of Energy, "Test Procedures for Central Air Conditioners, Including Heat Pumps," Department of Energy Final Rule, Federal Register, Vo1. 44, No. 249, December 27, 1979. 


\section{APPENDIX A}

\section{DERIVATION OF MODIFIED UNIFORM PRESENT WORTH FACTORS}

One of the most critical aspects of a life-cycle cost analysis is that of evaluating a flow of future benefits or costs associated with some design change in present-value terms. In general, this requires that future benefits or costs be discounted to present value using an appropriate discount rate. The purpose of this appendix is to show the derivation of modified uniform present worth (UPW*) factors that can be used to evaluate the present value of energy savings over the life of an appliance. 1

Dollar-valued energy savings can be calculated for each year over the life of a design modification and discounted to present value. However, if the physical energy savings are assumed constant from year to year, it is generally easier to calculate a modified uniform present worth factor which, when multiplied by the annual energy savings calculated at the cost of energy in the initial time period, will produce the same results.

That is:

$$
\left(\begin{array}{l}
\text { present value } \\
\text { life-cycle } \\
\text { savings }
\end{array}\right)=U P W^{*} \times\left(\begin{array}{l}
\text { annual } \\
\text { energy } \\
\text { savings }
\end{array}\right) \times\left(\begin{array}{l}
\text { price of energy } \\
\text { at initial time } \\
\text { period }
\end{array}\right)
$$

The UPW* factor is a function of the life over which the savings are expected to be realized, the discount rate, and the rate at which energy prices are expected to increase over the life of the modification. If the discount rate and the rate of energy price escalation are constant over the life of the appliance the modified uniform present worth factor can be calculated using:

$$
U P W^{*}=\sum_{t=1}^{L}\left(\frac{1+P}{1+D}\right)^{t}
$$

$$
\text { where } \begin{aligned}
& L=\text { the lifetime of the appliance (in years), } \\
& P=\text { the annual rate of price increase for energy, and } \\
& D=\text { the discount rate. }
\end{aligned}
$$

Note that if $P=D$, the increase in fuel prices just offsets the discount rate so that the UPW ${ }^{*}$ is equal to the lifetime in years, i.e., the savings are simply added each year at initial year energy prices.

1 The term "modified" is used to describe a uniform present worth factor which incorporates an increasing cash flow over time rather than a conventional UPW factor which is based on a constant cash flow over time. 
If $P$ does not equal $D$, equation $A-1$ can be reformulated as:

$$
U P W^{*}=\left(\frac{1+P}{D-P}\right)\left(1-\left(\frac{1+P}{1+D}\right)^{L}\right) \cdot
$$

Alternatively, if the rate of energy price increase is not constant over the life of the appliance, but is expected to change n-1 times at specified points in time, the UPW* can be evaluated as

$$
\left.U P W^{*}=\sum_{i=1}^{n} \prod_{j=0}^{i-1}\left(\frac{1+P}{1+D}\right)^{T_{j}}\right]\left(\frac{1+P}{D-P} j\right)\left(1-\left(\frac{1+P}{1+D}\right)^{T_{i}}\right)
$$

where: $\mathrm{n}=$ number of time intervals,

$T_{i}=$ length of time interval $i$,

$\mathrm{T}_{j}=$ length of time interval $j\left(\mathrm{~T}_{0}=0\right)$, and

$P_{j}=$ rate of price increase in time interval $j\left(P_{0}=0\right)$. 
U. DEPT OF COMM.

BIBLIOGRAPHIC DATA

SHEET (See instructions)
1. PUBLICATION OR REPORT NO.

NBSIR $81-2241$

4. TITLE AND SUBTITLE ENGINEERING - ECONOMIC ANALYSIS OF IMPROVED HEAT PUMP PERFORMANCE FOR MINIMUM STANDARDS DEVELOPMENT

5. AUTHOR(S)

Stephen R. Petersen, Kimberly A. Barnes, and George E. Kelly

6. PERFORMING ORGANIZATION (If joint or other than NBS, see instructions)

7. Contract/Grant No.

NATIONAL BUREAU OF STANDARDS

DEPARTMENT OF COMMERCE

WASHINGTON, D.C. 20234

8. Type of Report \& Period Covered Final

9. SPONSORING ORGANIZATION NAME AND COMPLETE ADORESS (Street, CITY, StOte, ZIP)

U.S. Department of Energy

Washington, D.C. 20461

10. SUPPLEMENTARY NOTES

Document describes a computer program; SF-185, FIPS Software Summary, is attached.

11. ABSTRACT (A 200-word or less foctual summary of most significant information. If document includes a significant bibliogrophy or literoture survey, mention it here)

This report provides a methodology and seasonal performance data that could be used in the development of a reference basis for minimum efficiency standards for heat pumps that are economically justified on a life-cycle basis. Criteria for economic optimization are outlined. The methodology used to compute seasonal heating and cooling performance ratings and the annual energy savings resulting from efficiency improvements, by climate region, is detailed. The interdependence between efficiency ratings in the heating and cooling modes is explored using statistical analysis. An example of the procedure for determining maximum costeffective efficiency levels is demonstrated for a $36,000 \mathrm{Btu} / \mathrm{h}$ heat pump.

12. KEY WORDS (Six to twelve entries; alphabetical order; capitalize only proper names; and separate key words by semicolons) Energy efficiency standards; engineering-economic analysis; heat pump; mechanical equipment efficiency ratings; minimum efficiency standards; space cooling requirements; space heating requirements.

13. AVAILABILITY

×x Unlimited

For Official Distribution. Do Not Release to NTIS

Order From Superintendent of Documents, U.S. Government Printing Office, Washington, D.C. 20402.

Order From National Technical Information Service (NTIS), Springfield, VA. 2216I

14. NO. OF PRINTED PAGES

85

15. Price

$\$ 9.50$ 
